Prepared in cooperation with the Massachusetts Office of Coastal Zone Management

\title{
Shallow Geology, Sea-Floor Texture, and Physiographic Zones of the Inner Continental Shelf From Aquinnah to Wasque Point, Martha's Vineyard, and Eel Point to Great Point, Nantucket, Massachusetts
}

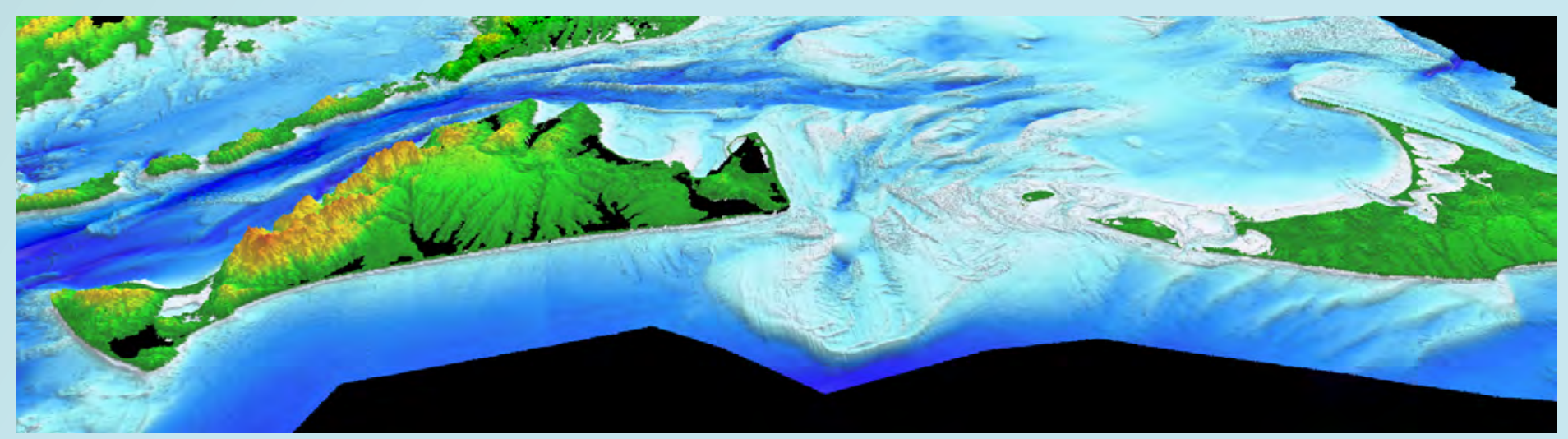

Open-File Report 2018-1181 
Cover. North-looking oblique aerial view of topography and bathymetry of Martha's Vineyard and Nantucket, Massachusetts. Image by the U.S. Geological Survey. 


\section{Shallow Geology, Sea-Floor Texture, and Physiographic Zones of the Inner Continental Shelf From Aquinnah to Wasque Point, Martha's Vineyard, and Eel Point to Great Point, Nantucket, Massachusetts}

By Elizabeth A. Pendleton, Wayne E. Baldwin, Seth D. Ackerman, David S. Foster, Brian D. Andrews, William C. Schwab, and Laura L. Brothers

Prepared in cooperation with the

Massachusetts Office of Coastal Zone Management

Open-File Report 2018-1181 


\title{
U.S. Department of the Interior \\ DAVID BERNHARDT, Acting Secretary
}

\author{
U.S. Geological Survey \\ James F. Reilly II, Director
}

U.S. Geological Survey, Reston, Virginia: 2019

For more information on the USGS - the Federal source for science about the Earth, its natural and living resources, natural hazards, and the environment-visit https://www.usgs.gov or call 1-888-ASK-USGS.

For an overview of USGS information products, including maps, imagery, and publications,

visit https://store.usgs.gov.

Any use of trade, firm, or product names is for descriptive purposes only and does not imply endorsement by the U.S. Government.

Although this information product, for the most part, is in the public domain, it also may contain copyrighted materials as noted in the text. Permission to reproduce copyrighted items must be secured from the copyright owner.

Suggested citation:

Pendleton, E.A., Baldwin, W.E., Ackerman, S.D., Foster, D.S., Andrews, B.D., Schwab, W.C., and Brothers, L.L., 2019, Shallow geology, sea-floor texture, and physiographic zones of the inner continental shelf from Aquinnah to Wasque Point, Martha's Vineyard, and Eel Point to Great Point, Nantucket, Massachusetts: U.S. Geological Survey Open-File Report 2018-1181, 37 p., https://doi.org/10.3133/ofr20181181.

ISSN 2331-1258 (online) 


\section{Acknowledgments}

This research was done in cooperation with the Massachusetts Office of Coastal Zone

Management. This manuscript benefited from thoughtful scientific reviews by Jason Chaytor and Ben Gutierrez of the U.S. Geological Survey. 



\section{Contents}

Acknowledgments ……...................................................................................................................

Abstract

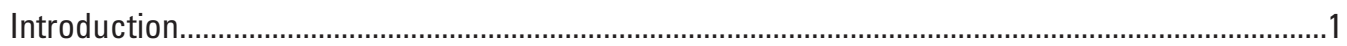

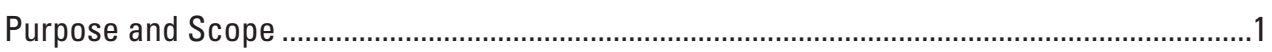

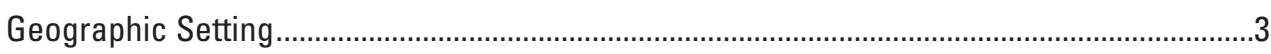

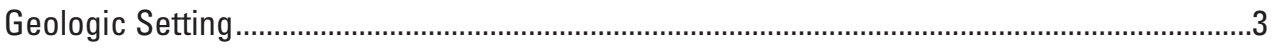

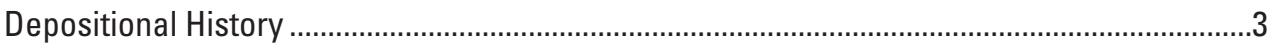

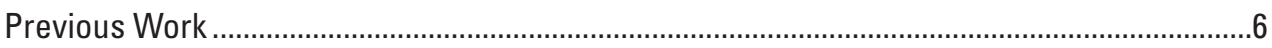

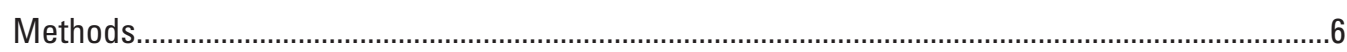

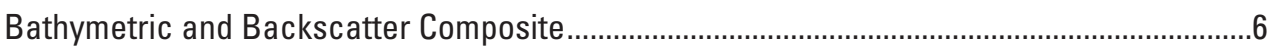

Seismic Stratigraphic and Surficial Geologic Mapping ........................................................

Sediment Samples and Sediment Texture Classification Schemes.........................................10

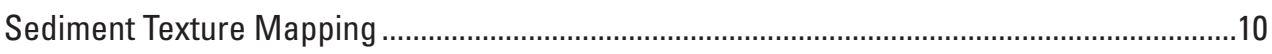

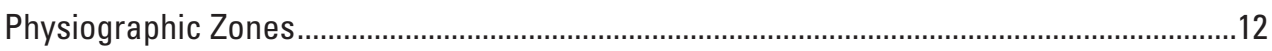

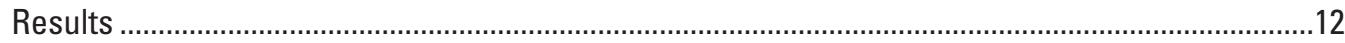

Seismic Stratigraphy and Geologic Interpretation ...........................................................12

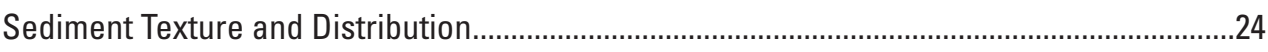

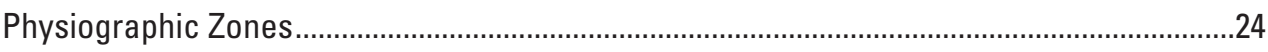

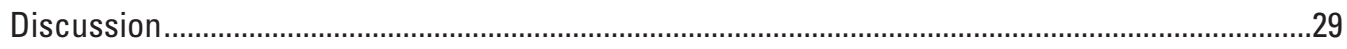

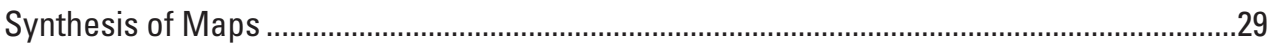

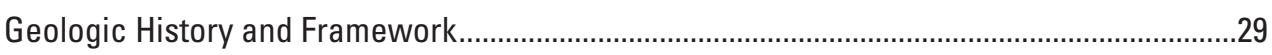

Glacial Recession .................................................................................................30

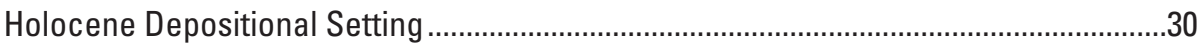

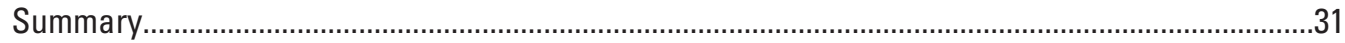

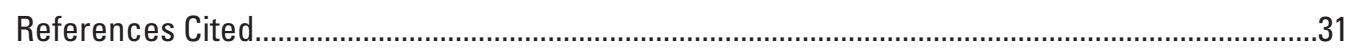

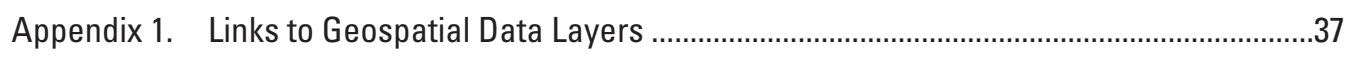

\section{Figures}

1. Location map of the Martha's Vineyard and Nantucket study sites, and inset map locating the study area within southern New England ..........................................

2. Map showing a digital elevation model of the study area...............................................

3. Map showing glacial moraines on land and submerged on the continental shelf, ice-front locations for southern New England, and glacial lakes and associated spillways

4. Map showing a composite backscatter image of the study area, created from a series of published backscatter images......................................................................

5. Map showing tracklines of chirp seismic-reflection profiles used to interpret surficial geology and shallow stratigraphy.

6. Map showing locations of observations of sea-floor composition used to aid the geophysical and geologic interpretations.................................................................11

7. Diagram showing Barnhardt and others (1998) bottom-type classification based on four basic sediment units: rock, gravel, sand, and mud.. 
8. Map showing the distribution of confidence levels for sediment texture and physiographic zone interpretations..

9. Seismic stratigraphic section showing units and major unconformities interpreted within Vineyard Sound and eastern Rhode Island Sound

10. Chirp seismic-reflection profile $A-A^{\prime}$ with seismic stratigraphic interpretation.............15

11. Chirp seismic-reflection profile $B-B^{\prime}$ with seismic stratigraphic interpretation.............16

12. Geologic sections $\left(C-C^{\prime}, D-D^{\prime}\right.$, and $\left.E-E^{\prime}\right)$ illustrating the general distributions and thicknesses of seismic stratigraphic units and major unconformities in the Martha's Vineyard and Nantucket, Massachusetts, study sites

13. Chirp seismic-reflection profile $F-F^{\prime}$ with seismic stratigraphic interpretation ..............18

14. Chirp seismic-reflection profile $G-G{ }^{\prime}$ with seismic stratigraphic interpretation.............19

15. Map showing the surficial geology from this study and Baldwin and others (2016) with equivalent onshore geology.

16. Map showing the elevation of the late Wisconsinan to early Holocene regressive unconformity $\mathrm{U}_{\mathrm{r}^{\prime}}$, which identifies the eroded surface of Pleistocene glacial drift offshore.....

17. Map showing the thickness of postglacial fluvial and estuarine (Qfe) and Holocene nearshore marine $(0 \mathrm{mn})$ sediments...

18. Map showing the distribution of sediment textures within the study area

19. Map and photographs showing sediment textures offshore of western and southern Martha's Vineyard

20. Map and photographs showing sediment textures offshore of northern Nantucket

21. Map showing the distribution of physiographic zones

\section{Tables}

1. Data sources for bathymetry, backscatter, and seismic-reflection profile interpretations for the south and west shore of Martha's Vineyard and the north shore of Nantucket, Massachusetts.

2. Confidence levels assigned to sediment texture and physiographic zone polygons on the basis of the data used in the interpretation. 


\section{Conversion Factors}

International System of Units to U.S. customary units

\begin{tabular}{|c|c|c|}
\hline Multiply & By & To obtain \\
\hline \multicolumn{3}{|c|}{ Length } \\
\hline centimeter $(\mathrm{cm})$ & 0.3937 & inch (in.) \\
\hline millimeter $(\mathrm{mm})$ & 0.03937 & inch (in.) \\
\hline meter $(\mathrm{m})$ & 3.281 & foot (ft) \\
\hline kilometer $(\mathrm{km})$ & 0.6214 & mile (mi) \\
\hline kilometer $(\mathrm{km})$ & 0.5400 & mile, nautical (nmi) \\
\hline meter $(\mathrm{m})$ & 1.094 & yard (yd) \\
\hline \multicolumn{3}{|c|}{ Area } \\
\hline square kilometer $\left(\mathrm{km}^{2}\right)$ & 0.3861 & square mile $\left(\mathrm{mi}^{2}\right)$ \\
\hline
\end{tabular}

\section{Datum}

Vertical coordinate information is referenced to North American Vertical Datum of 1988 (NAVD 88).

Horizontal coordinate information is referenced to the World Geodetic System of 1984 (WGS 84) in a geographic coordinate system.

Elevation, as used in this report, refers to distance above the vertical datum.

\section{Supplemental Information}

Particle size in phi units may be converted to millimeters $(\mathrm{mm})$ as $\mathrm{mm}=2^{- \text {phi }}$.

\section{Abbreviations}

CZM

DEM

GIS

ka

$\mathrm{kHz}$

lidar

mpp

USGS
Massachusetts Office of Coastal Zone Management

digital elevation model

geographic information system

kiloannum, thousands of years before the present

kilohertz

light detection and ranging

meter per pixel

U.S. Geological Survey 



\title{
Shallow Geology, Sea-Floor Texture, and Physiographic Zones of the Inner Continental Shelf From Aquinnah to Wasque Point, Martha's Vineyard, and Eel Point to Great Point, Nantucket, Massachusetts
}

\author{
By Elizabeth A. Pendleton, Wayne E. Baldwin, Seth D. Ackerman, David S. Foster, Brian D. Andrews, \\ William C. Schwab, and Laura L. Brothers
}

\section{Abstract}

A series of interpretive maps that describe the shallow geology, distribution, and texture of sea-floor sediments, and physiographic zones of the sea floor along the south and west shores of Martha's Vineyard and the north shore of Nantucket, Massachusetts, were produced by using high-resolution geophysical data (interferometric and multibeam swath bathymetry, light detection and ranging [lidar] bathymetry, backscatter intensity, and seismic-reflection profiles), sediment samples, and bottom photographs. These interpretations are intended to aid statewide efforts to inventory and manage coastal and marine resources, link with existing data interpretations, and provide information for research focused on coastal evolution and environmental change. Marine geologic mapping of the inner continental shelf of Massachusetts is a statewide cooperative effort of the U.S. Geological Survey and the Massachusetts Office of Coastal Zone Management.

\section{Introduction}

The geologic framework and seabed character of the coastal zone of Massachusetts is complex, heterogeneous, and controlled by the antecedent geology. Previous studies in the region defined the geology and texture of the sea floor on the basis of widely spaced geophysical tracklines and vibracores (O'Hara and Oldale, 1980, 1987) or sediment samples (Ford and Voss, 2010). In this study, high-resolution geophysical datasets at full sea-floor coverage, supplemented with sediment samples and bottom photographs, provide the basis for detailed surficial to shallow stratigraphic geologic maps, highresolution sediment texture maps, and physiographic zone delineations that were previously unfeasible because of a lack of high-quality, high-density sea-floor mapping data.

\section{Purpose and Scope}

This report describes the shallow geologic framework, distribution of sea-floor texture, and physiographic zones of the Massachusetts coastal zone between Aquinnah and Wasque Point on Martha's Vineyard, and between Eel Point and Great Point on Nantucket, Massachusetts (fig. 1). Interpretations are provided as geospatial data layers in a companion data release (appendix 1; Pendleton and others, 2018, https://doi.org/10.5066/P9E9EFNE). This research was carried out as part of a cooperative sea-floor mapping program (https://woodshole.er.usgs.gov/project-pages/coastal_mass/) between the U.S. Geological Survey (USGS) and the Massachusetts Office of Coastal Zone Management (CZM). This cooperative effort fosters data collection and the production of interpretive geospatial datasets that can be used by managers and scientists to delineate marine resources, assess environmental change, inventory marine habitats, and support research concerning sea-level change, sediment supply and budget, and coastal evolution (Massachusetts Office of Coastal Zone Management, 2015).

The maps presented in this report are based on interpretation of high-resolution seismic-reflection profiles, swath bathymetry, acoustic backscatter, bottom photographs, and sediment samples collected within nearshore regions (less than about 30-meter [m] water depth; Denny and others, 2009; Andrews and others, 2014, 2018; Ackerman and others, 2016); bottom photographs and sediment samples (Ackerman and others, 2016); and sediment texture databases (Ford and Voss, 2010; McMullen and others, 2012) modified by CZM (Emily Huntley, CZM, unpub. data, 2012). This report is the fifth in a series of geologic interpretative datasets and reports (Pendleton and others, 2013, 2015; Foster and others, 2015; Baldwin and others, 2016) about Massachusetts State waters that have been published as part of the USGS and CZM cooperative mapping agreement. 

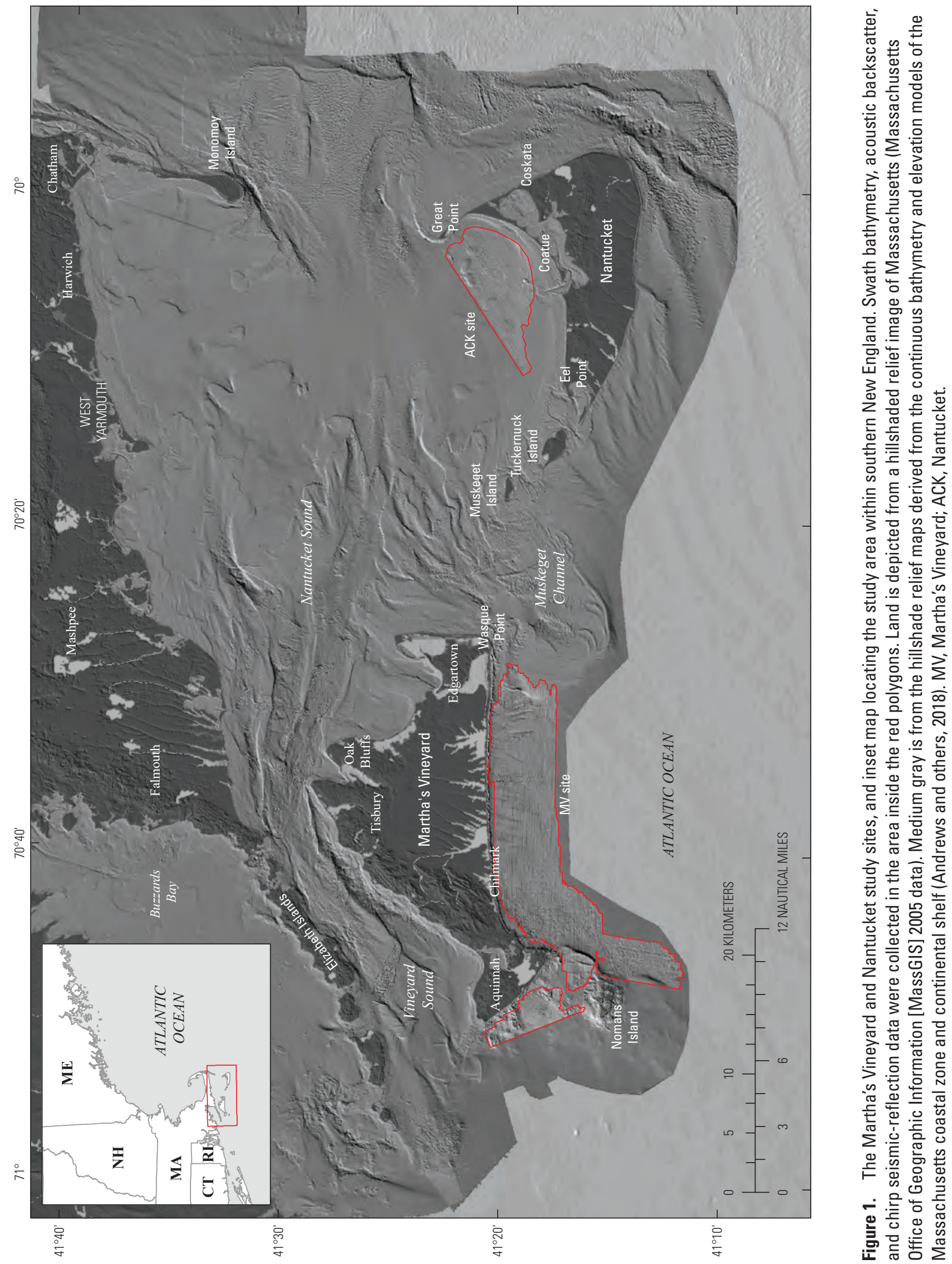


\section{Geographic Setting}

Martha's Vineyard and Nantucket are the two largest islands in southeastern Massachusetts and are approximately 6 and 45 kilometers $(\mathrm{km})$ south of Cape Cod, respectively (fig. 1). The study area includes the inner continental shelf just west and south of Martha's Vineyard, between Aquinnah and Muskeget Channel, and north of Nantucket Island, between Tuckernuck Island and Great Point (fig. 1). The two sites described in this study are (1) an area that lies along the open Atlantic coast of Martha's Vineyard, referred to as the Martha's Vineyard site and (2) another mostly protected area that lies on the north side of Nantucket within Nantucket Sound, referred to as the Nantucket site. The Martha's Vineyard site occupies nearly $38 \mathrm{~km}$ of shoreline offshore of the south and west of Martha's Vineyard and has a mean water depth of approximately $18 \mathrm{~m}$ (below North American Vertical Datum of 1988 [NAVD 88]; fig. 2). This area reaches depths exceeding $30 \mathrm{~m}$ south and east of Nomans Island. The Nantucket site covers roughly 12 of the $17 \mathrm{~km}$ of Nantucket Sound that lies between North Point and Great Point, has a mean water depth of $12 \mathrm{~m}$ below NAVD 88, and gently shallows to the south toward Nantucket Harbor.

The south coast of Martha's Vineyard east of Chilmark is primarily a low-relief, gently south-sloping sand and gravel plain that is incised by linear, shore-perpendicular coastal embayments (drowned valleys) fronted by welded barrier beaches and spits (Uchupi and Oldale, 1994). The Atlantic coast of Aquinnah and Chilmark, including Gay Head and Squibnocket Point, is higher but also more variable in elevation. These areas are distinctly rockier than the southeast coast of Martha's Vineyard. Between cliffed areas are lower elevation pocket and welded barrier beaches, backed by coastal ponds.

The north coast of Nantucket, west of Nantucket Harbor, consists of low, unconsolidated cliffs fronted by a sandy beach along Nantucket Sound. The coast along the east side of Nantucket from Great Point to Coskata is a barrier spit that shelters the study site, and another spit that builds from Coskata to the west encloses Nantucket Harbor. The latter spit is between 100 and $500 \mathrm{~m}$ wide, with a straight sandy beach facing Nantucket sound and a sandy, cuspate coast facing into Nantucket Harbor.

\section{Geologic Setting}

The geologic framework of Martha's Vineyard and Nantucket is controlled by the underlying bedrock and coastal plain and continental shelf units, subsequent Pleistocene glaciations, and Holocene sea-level rise (O'Hara and Oldale, 1980, 1987). Basement rocks of Triassic and Cretaceous ages underlie the islands at depths below the land surface of between 150 and $300 \mathrm{~m}$ on Martha's Vineyard and up to $500 \mathrm{~m}$ on Nantucket (Oldale, 1969; Zen and others, 1983). The basement is unconformably overlain by coastal plain and continental shelf deposits (Woodsworth and Wigglesworth, 1934; Kaye, 1964a, b, 1980; Oldale and others, 1973; Folger and others, 1978; Hall and others, 1980; O'Hara and Oldale, 1980, 1987; Oldale and O'Hara, 1984). These deposits are composed of unconsolidated to semiconsolidated sand, silty clay, and gravel, and they represent a wedge of coastal plain and continental shelf strata that dips and thickens to the south (Weed and others, 1974; O'Hara and Oldale, 1980, 1987; Siegel and others, 2012).

Glacial drift, deposited during the Illinoian and Wisconsinan Ages of the Pleistocene, unconformably overlies the basement rocks and coastal plain and continental shelf deposits (Woodsworth and Wigglesworth, 1934; Kaye, 1964a, b; O'Hara and Oldale, 1980, 1987; Oldale, 1981, 1982, 2001; Oldale and others, 1982; Uchupi and others, 1996; Masterson and others, 1997; Stone and DiGiacomo-Cohen, 2009). The glacial drift includes poorly sorted tills and moraines, which suggest ice-proximal deposition, and moderately to well sorted and stratified glaciofluvial and glaciolacustrine units, which indicate ice-distal deposition (Kaye, 1964a; b; Oldale and Barlow, 1986; Stone and DiGiacomo-Cohen, 2009).

Postglacial deposits primarily consist of material that has been winnowed from the glacial drift by marine and fluvial processes during the late Pleistocene and Holocene (O'Hara and Oldale, 1980, 1987; Oldale, 1982, 2001). The oldest postglacial deposits are fluvial and estuarine units that fill glaciofluvial channels and other topographic lows on the surface of the glacial drift (O'Hara and Oldale, 1980, 1987). The Holocene marine transgressive unconformity separates the older units from younger overlying postglacial marine deposits. The marine units primarily consist of shelf sand bodies offshore of Martha's Vineyard, including thin and discontinuous sand veneers, ebb-tidal deltas, and sorted bedforms (Goff and others, 2005), but the modern marine unit on the north side of Nantucket is a muddy sand sheet (O'Hara and Oldale, 1987).

\section{Depositional History}

Between 28 and 25.5 thousand years before present $(\mathrm{ka})$, the Buzzards Bay and Cape Cod Bay lobes of the Wisconsinan Laurentide Ice Sheet reached their maximum southern extents near Martha's Vineyard and Nantucket (fig. 3; Uchupi and others, 1996; Oldale, 2001; Balco and others, 2002; Uchupi and Mulligan, 2006; Balco, 2011). The overburden of the advancing ice front locally deformed and thrusted previously deposited glacial drift and underlying coastal plain and continental shelf units into the terminal moraines that now form the western and northeastern coasts of Martha's Vineyard and Nantucket, respectively (Woodsworth and Wigglesworth, 1934; Kaye, 1964a, b; Oldale and Eskenasy, 1982; Oldale and O'Hara, 1984; Oldale, 2001; Stone and DiGiacomo-Cohen, 2009). The Buzzards Bay ice lobe deposited the end moraine that makes up Nomans Island and the western side of Martha's Vineyard, and the Cape Cod Bay lobe deposited the end moraines present on the eastern side of Martha's Vineyard and 


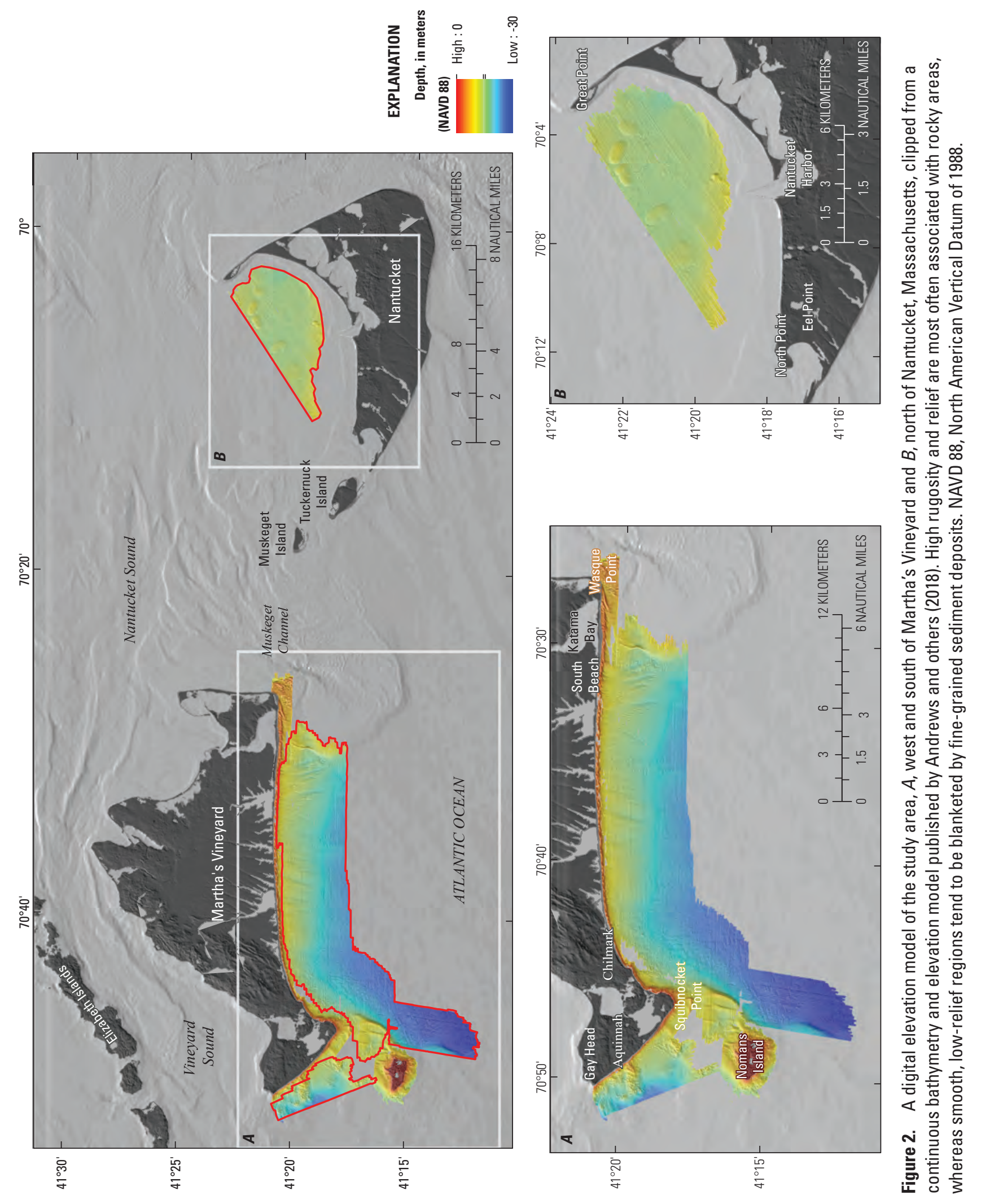




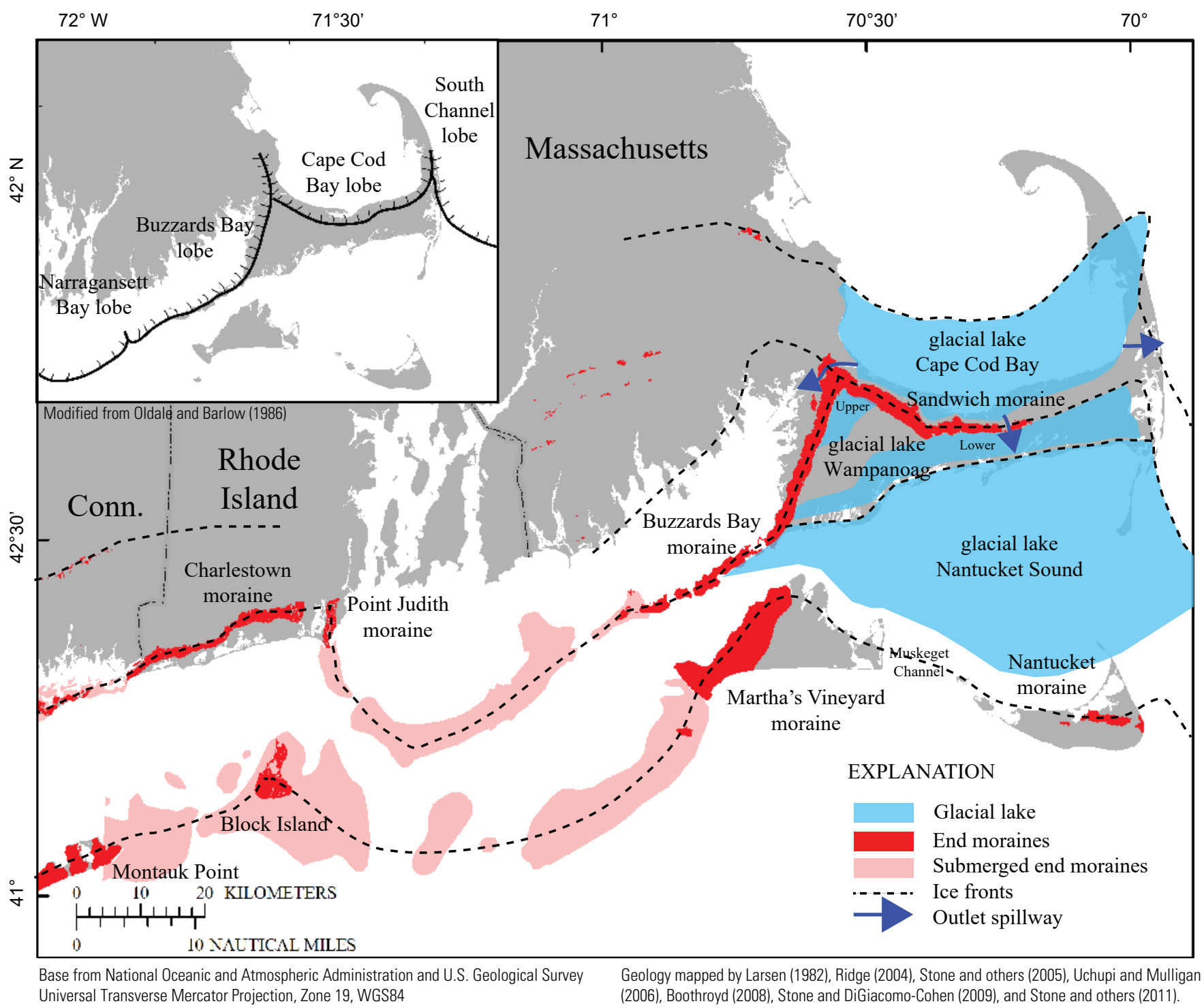

Figure 3. Glacial moraines on land and submerged on the continental shelf (compiled from Stone and others, 2005; Boothroyd, 2008; Stone and DiGiacomo-Cohen, 2009; and Stone and others, 2011), ice-front locations for southern New England (from Ridge, 2004), and glacial lakes and associated spillways (compiled from Larson, 1982; Uchupi and Mulligan, 2006). Inset illustrates the relative locations of four lobes of the Laurentide Ice Sheet in southeastern New England (modified from Oldale and Barlow, 1986). Figure is from Baldwin and others (2016), modified from Foster and others (2015). 
Shallow Geology, Sea-Floor Texture, and Physiographic Zones Offshore Martha's Vineyard and Nantucket, Mass.

on Nantucket (Larson, 1982; Oldale and Barlow, 1986; Oldale, 2001; Stone and DiGiacomo-Cohen, 2009). Coarse and poorly sorted till and ice-contact material were deposited proximal to the ice lobe termini, whereas finer grained and stratified fluvial outwash, lacustrine, and delta material was deposited beyond the ice front. Ice-contact deposits associated with the Buzzards Bay lobe are around western Martha's Vineyard, whereas stratified drift deposits associated with the Cape Cod Bay lobe formed the expansive outwash plains on Martha's Vineyard and Nantucket south and offshore of the terminal moraines (Kaye, 1972; Oldale and Barlow, 1986; Stone and DiGiacomoCohen, 2009).

The outwash plains of Martha's Vineyard were subsequently incised by north-south-trending sapping valleys that continued onto the continental shelf (O'Hara and Oldale, 1980; Uchupi and Oldale, 1994; Goff and others, 2005; Stone and DiGiacomo-Cohen, 2009). These groundwater drainage systems formed as a result of the high hydrostatic heads and shallow water table associated with proglacial lakes to the north and the high permeability of the outwash sediments (Uchupi and Oldale, 1994). The glacial landscape south of Martha's Vineyard was modified as an eroding drift sheet exposed at the surface, until approximately 10 to $8 \mathrm{ka}$ when sea level began to rise (O'Hara and Oldale, 1980; Gutierrez and others, 2003). Subsequently, oceanographic processes began reworking, winnowing, and redistributing fine-grained material from the glacial drift (O'Hara and Oldale, 1980; Goff and others, 2005). Sand bodies began accumulating on the shelf, sandy beaches formed along the south and west coast of Martha's Vineyard fronting outwash plains and moraines, and sapping valleys were progressively drowned.

In Nantucket Sound, proglacial lake deposits and a postglacial drainage network carved through outwash, and glaciodeltaic sediments underlie a deposit of Holocene estuarine and marine sediments (fig. 3; Larson, 1982; O'Hara and Oldale, 1987; Uchupi and Mulligan, 2006). Sheltered marine conditions along the north shore of Nantucket have resulted in the deposition of a modern muddy sand sheet between Great Point and North Point, and barrier spits have enclosed Nantucket Harbor (Rosen 1972; O'Hara and Oldale, 1987).

\section{Previous Work}

O'Hara and Oldale $(1980,1987)$ conducted comprehensive geologic mapping studies of eastern Rhode Island Sound, Vineyard Sound, and Nantucket Sound. They collected widely spaced (approximately $2,000 \mathrm{~m}$ apart) boomer seismicreflection profiles, sidescan sonographs, and vibracores. Their interpretations described the broad stratigraphic framework in a series of subsurface and sea-floor geologic maps, including structural contours of depths to the surfaces of pre-Quaternary coastal plain and continental shelf units, Quaternary glacial units, and isopachs of glacial and postglacial sediments. Legacy reports by Robb and Oldale (1977) and O'Hara and Oldale $(1980,1987)$ and two products of the USGS and CZM cooperative program (Foster and others, 2015; Baldwin and others, 2016), all of which focused on areas of Buzzards Bay and Vineyard and Nantucket Sounds, provided a foundation for this report. The geology and shallow structure of the south shore of Martha's Vineyard between Squibnocket Point and Wasque Point have not been previously published. Surficial geologic maps of Martha's Vineyard and Nantucket by Oldale and Barlow (1986) and Stone and DiGiacomo-Cohen (2009) were used to correlate onshore and offshore geologic units where possible.

\section{Methods}

This section describes how the interpretations presented in this report and the companion data release (Pendleton and others, 2018, https://doi.org/10.5066/P9E9EFNE) were generated. Detailed descriptions of software, source information, scale, and accuracy assessments for each dataset are provided in the metadata files for geospatial data layers in the data release. High-resolution bathymetric, acoustic-backscatter, and seismic-reflection data collected by the USGS, the National Oceanic and Atmospheric Administration, and the U.S. Army Corps of Engineers provide nearly full coverage of the sea floor in the 265-square-kilometer $\left(\mathrm{km}^{2}\right)$ study area (fig. 1, table 1). The geophysical data, sediment samples, and seafloor photographs/video allowed for interpretation of sea-floor composition and shallow subsurface stratigraphy at finer scales and resolutions than previously possible. However, the interpretations have limitations, which primarily arise from the types, quality, and density of data from which they were made. Pendleton and others (2013) provide detailed discussion regarding the limitations associated with these surficial mapping methods. Consequently, qualitative confidence levels were assigned to some interpretations and must be considered when surficial maps are used to guide management decisions and research.

\section{Bathymetric and Backscatter Composite}

A continuous bathymetry and elevation model published by Andrews and others (2018) that uses previously published elevation data covers the entire study area (fig. 2) and provided the seamless bathymetric data source for this study. Vertical resolutions of the source data range from unknown, for lead-line soundings, to $0.1 \mathrm{~m}$, for interferometric, multibeam, and light detection and ranging (lidar) swath bathymetric data.

A seamless acoustic-backscatter image was also created (fig. 4) from data previously published by the USGS (table 1). All source backscatter imagery was mosaicked into a composite GeoTIFF by using PCI Geomatica (version 10.1) with a resolution of 5 meters per pixel (mpp). 


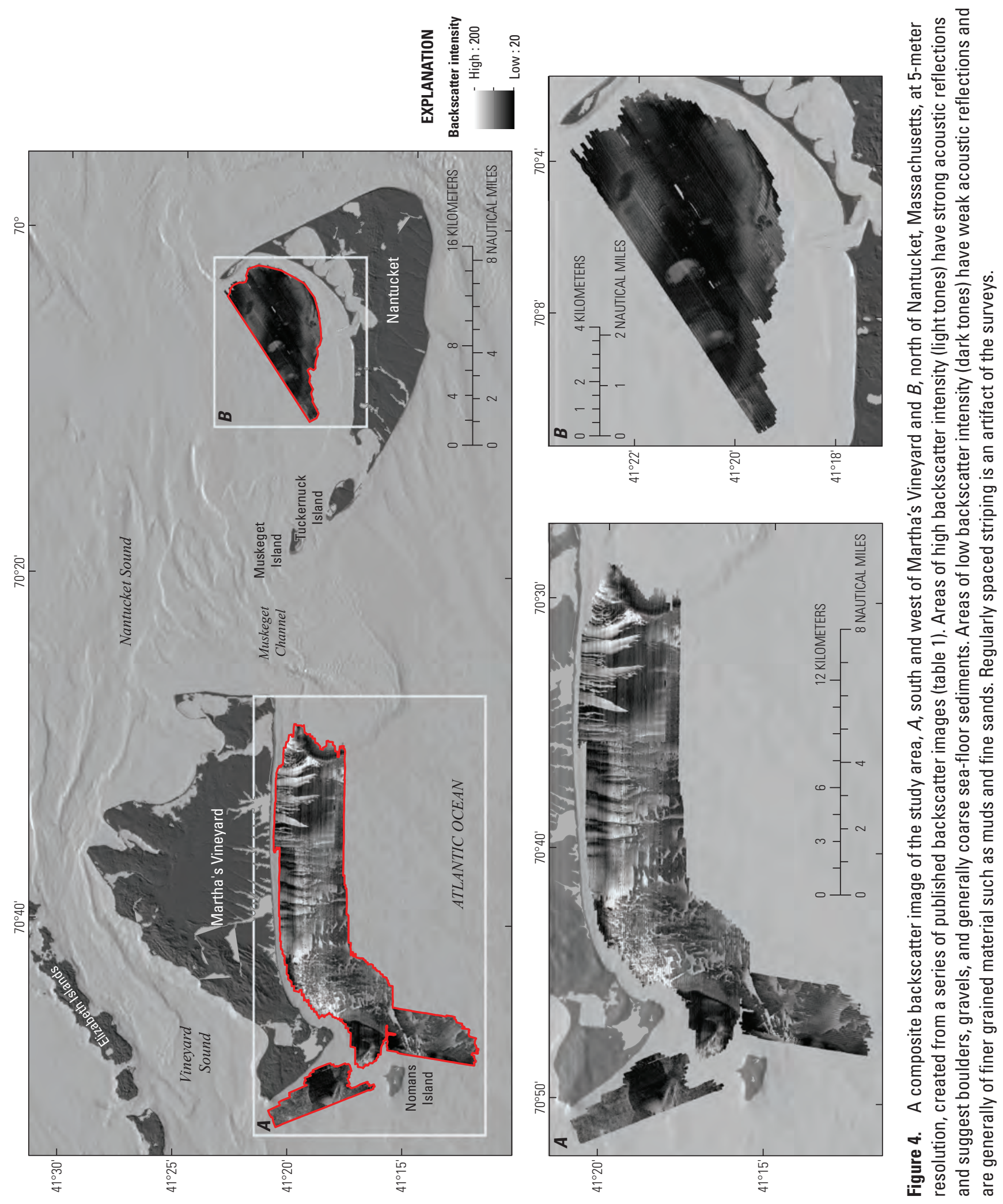


Table 1. Data sources for bathymetry, backscatter, and seismic-reflection profile interpretations for the south and west shore of Martha's Vineyard and the north shore of Nantucket, Massachusetts.

[kHz, kilohertz]

\begin{tabular}{|c|c|c|c|c|c|}
\hline Vessel & Date & Bathymetry & Acoustic backscatter & Seismic reflection & Citation \\
\hline Megan T. Miller ${ }^{1}$ & 2007 & $\begin{array}{l}\text { SEA SWATHplus 234- } \\
\text { kHz interferometric } \\
\text { sonar system }\end{array}$ & $\begin{array}{l}\text { Klein } 3000 \text { dual- } \\
\text { frequency sidescan } \\
\text { sonar }\end{array}$ & $\begin{array}{l}\text { EdgeTech Geo-Star FSSB } \\
\text { subbottom profiling } \\
\text { system and an SB-0512i } \\
\text { towfish }\end{array}$ & $\begin{array}{l}\text { Denny and others } \\
\text { (2009) }\end{array}$ \\
\hline $\begin{array}{l}\text { Megan T. Miller and } \\
\quad \text { Scarlet Isabella }\end{array}$ & 2009-2011 & $\begin{array}{l}\text { SEA SWATHplus 234- } \\
\text { kHz interferometric } \\
\text { sonar system }\end{array}$ & $\begin{array}{l}\text { Klein } 3000 \text { dual- } \\
\text { frequency sidescan } \\
\text { sonar }\end{array}$ & $\begin{array}{l}\text { EdgeTech Geo-Star FSSB } \\
\text { subbottom profiling } \\
\text { system and an SB-0512i } \\
\text { towfish }\end{array}$ & $\begin{array}{l}\text { Andrews and others } \\
\text { (2014) }\end{array}$ \\
\hline Scarlet Isabella ${ }^{1}$ & 2013 & $\begin{array}{l}\text { SWATHplus 234-kHz } \\
\text { interferometric sonar } \\
\text { system }\end{array}$ & $\begin{array}{l}\text { SWATHplus } 234 \mathrm{kHz} \\
\text { and EdgeTech } 4200 \\
\text { at } 100 \text { and } 400 \mathrm{kHz}\end{array}$ & $\begin{array}{l}\text { EdgeTech Geo-Star FSSB } \\
\text { subbottom profiling } \\
\text { system and an SB-0512i } \\
\text { towfish }\end{array}$ & $\begin{array}{l}\text { Ackerman and oth- } \\
\text { ers (2016) }\end{array}$ \\
\hline Various $^{1,2,3}$ & $1887-2016$ & $\begin{array}{l}\text { Lead-line, single-beam } \\
\text { sonar, multibeam sonar, } \\
\text { interferometric sonar, } \\
\text { and light detection and } \\
\text { ranging (lidar) }\end{array}$ & None & None & $\begin{array}{l}\text { Andrews and others } \\
\text { (2018) }\end{array}$ \\
\hline
\end{tabular}

${ }^{1}$ Data collected by the U.S. Geological Survey.

${ }^{2}$ Data collected by the National Oceanic and Atmospheric Administration.

${ }^{3}$ Data collected by the U.S. Army Corps of Engineers.

\section{Seismic Stratigraphic and Surficial Geologic Mapping}

Approximately 2,800 kilometers of seismic-reflection profiles, collected between 2007 and 2013 (table 1, fig. 5), were interpreted in The Kingdom Suite (version 8.8). The profiles were collected by using chirp sonars with broadband frequencies of 0.5 to 12 kilohertz $(\mathrm{kHz})$ or narrow-band frequencies centered around $3.5 \mathrm{kHz}$. Legacy seismic-reflection data (O'Hara and Oldale, 1980, 1987; McMullen and others, 2009) were used in the interpretations for general correlation with the seismic stratigraphy interpreted in previous studies. Interpretations of shallow stratigraphy and surficial geology were conducted in the time domain (two-way traveltime) and consisted of (1) identifying and defining seismic stratigraphic units on the basis of seismic facies, and digitizing reflectors (horizons) defining the boundaries between individual seismic stratigraphic units; and (2) digitizing the extent over which each of the defined seismic stratigraphic units crops out on the sea floor.

Two-way traveltime values for the postglacial seismic unit were exported and converted to thickness in meters by using a constant seismic velocity of 1,500 meters per second. The resulting isopach values were imported into ArcGIS as point features (easting, northing, thickness) and used to generate an interpolated digital elevation model (DEM) with a 40-mpp resolution. The isopach map of postglacial sediment was added to the DEM of regional swath bathymetry (fig. 2) to produce a DEM of the unconformity defining its base of postglacial material (40-m cell size, relative to NAVD 88 ).

The digitized sea-floor outcrops for each seismic unit were imported into ArcGIS as point features (easting, northing, seismic unit) and used to guide manual digitizing of polygons representing discrete areas of seismic-unit outcrop. The resulting polygon dataset provides a seamless representation of surficial geology for the seismic-reflection survey area. The surficial geology polygons also provide insight into the likely sediment texture at the sea floor based on the glacial or postglacial origin and depositional environment inferred from the seismic interpretation. The geologic observations were incorporated into surficial sediment texture mapping.

High-density seismic-reflection data were collected only within the areas surveyed by the USGS between 2007 and 2013 (table 1, fig. 5). As a result, surficial geology polygons derived from the seismic interpretations are less extensive than the polygons of sea-floor sediment texture and physiographic zones, which cover areas equivalent to the composite bathymetry (fig. 2). 


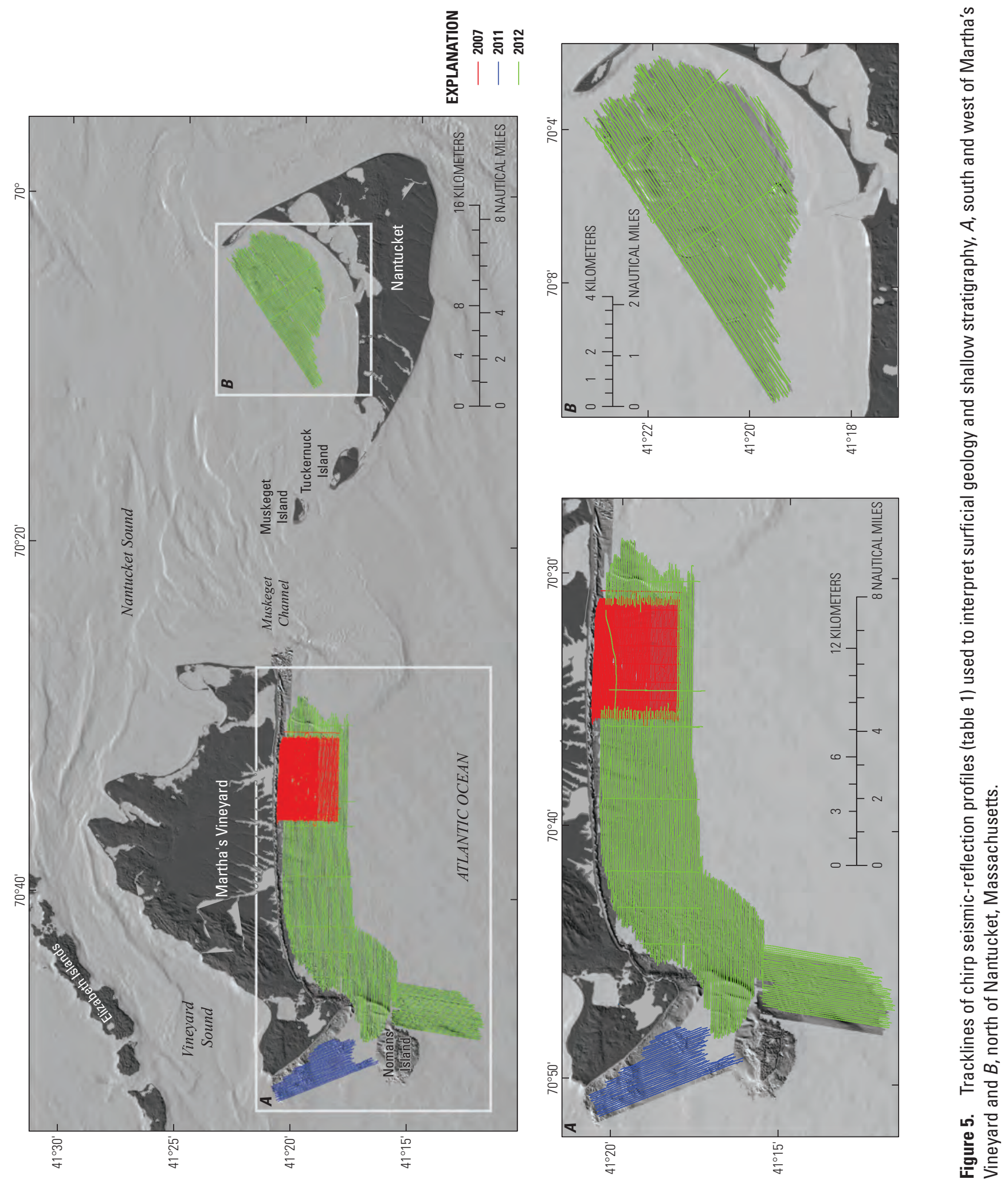




\section{Sediment Samples and Sediment Texture Classification Schemes}

Sediment sample databases of Ford and Voss (2010), McMullen and others (2012), and Ackerman and others (2016) were supplemented with visual descriptions from National Oceanic and Atmospheric Administration nautical charts and sea-floor photographs compiled by CZM (fig. 6; Emily Huntley, CZM, written commun., 2014). This study uses the Barnhardt and others (1998) sediment texture classification scheme (fig. 7). The Barnhardt and others (1998) system is based on four basic, easily recognized sediment units (as measured in grain size, based on Wentworth, 1922): rock (R; grain size greater than 64 millimeters [mm]), gravel (G; grain size 2 to $64 \mathrm{~mm}$ ), sand (S; grain size 0.062 to $2 \mathrm{~mm}$ ), and mud (M; grain size less than $0.062 \mathrm{~mm}$ ). Because the sea floor is often not a uniform mixture of these units, the classification is further divided into 12 composite units, which are two-part combinations of the 4 basic units (fig. 7). This classification is defined such that the primary texture, representing more than 50 percent of an area's texture, is given an uppercase letter, and the secondary texture, representing less than 50 percent of an area's texture, is given a lowercase letter. If one of the basic sediment units represents more than 90 percent of the texture, only its uppercase letter is used. The units defined under the Barnhardt and others (1998) classification within this study area are $\mathrm{R}$, gravelly rock $(\mathrm{Rg})$, sandy rock (Rs), and muddy rock (Rm); G, rocky gravel (Gr), sandy gravel (Gs), and muddy gravel (Gm); S, gravelly sand (Sg), muddy sand (Sm), and rocky sand ( $\mathrm{Sr}$ ); and $\mathrm{M}$, rocky mud (Mr), gravelly mud $(\mathrm{Mg})$, and sandy mud (Ms).

\section{Sediment Texture Mapping}

The texture and spatial distribution of sea-floor sediment were mapped qualitatively in ArcGIS by using acoustic-backscatter intensity, bathymetry, lidar, geologic interpretations, bottom photographs, and sediment samples. The highest data resolution that was available was used to map sea-floor sediment texture, typically 2 to $5 \mathrm{~m}$ in water depths less than $30 \mathrm{~m}$. First, sediment texture polygons were outlined by using backscatter intensity data to define changes in the sea floor based on acoustic return (fig. 4). Areas of high backscatter intensity (light tones) have strong acoustic reflections, suggest boulders and gravels, and generally are characterized by coarse sea-floor sediments. Areas of low backscatter intensity (dark tones) have weak acoustic reflections and generally are characterized by fine-grained material such as muds and fine sands.

The polygons were then refined and edited by using gradient, rugosity, and hillshaded relief images derived from interferometric and multibeam swath bathymetry and lidar at the highest resolution available (fig. 2). Areas of rough topography and high rugosity typically are associated with rocky areas, whereas smooth, low-rugosity regions tend to be blanketed by fine-grained sediment. These bathymetric derivatives helped to refine polygon boundaries where changes from areas of primarily rock to areas of primarily gravel may not have been apparent in backscatter data but could easily be identified in hillshaded relief, rugosity, and slope data.

The third data input was the stratigraphic and geologic interpretation of seismic-reflection profiles, which further constrained the extent and general shape of sea-floor sediment distributions and rocky outcrops and also provided insight concerning the likely sediment texture based on the pre-Quaternary, glacial, or postglacial origin (figs. 5; O'Hara and Oldale, 1980, 1987; Foster and others, 2015; Baldwin and others, 2016).

Finally, sediment texture data and bottom photographs were used to verify and refine the classification of the sediment texture polygons. Samples with laboratory analysis data, rather than qualitative descriptions, were preferred for defining sediment texture throughout the study area. Bottom photographs were also used to qualitatively define sediment texture, particularly in areas dominated by gravel- to bouldersize material. Many of the sediment type polygons did not contain sample information. For these polygons, sediment textures were extrapolated from similar sea-floor polygons that contained samples and produced similar acoustic-backscatter and seismic-reflection properties.

Sediment texture polygons were assigned one of four confidence levels on the basis of the type and quality of data used to define them (table 2). The confidence levels were attached as an attribute in the geographic information system (GIS) for each sediment texture polygon (fig. 8). Level-one confidence areas contain the widest variety of high-resolution geophysical data and the highest quality of sediment sample data. Level-two areas share the same variety of geophysical data but do not contain data from sediment samples that were analyzed quantitatively in the laboratory. Many leveltwo areas consist of gravel or gravelly sediment from which there was no attempt to collect a physical sample, or sample attempts recovered no material. This lack of samples is a common problem because either most bottom samplers are incapable of sampling gravel and cobble, or sufficient material cannot be collected for accurate quantitative laboratory analysis. Because level-three areas were designated in the absence of seismic-reflection data and possibly sediment samples with laboratory analyses, these areas are considered to have slightly less confidence than level-one and level-two areas. Level-four areas have substantially lower confidence because the primary component of the Barnhardt and others (1998) classification, acoustic reflectivity, is lacking. Consequently, levels one through three are generally considered "high confidence," and level four is considered "low confidence" (table 2). 


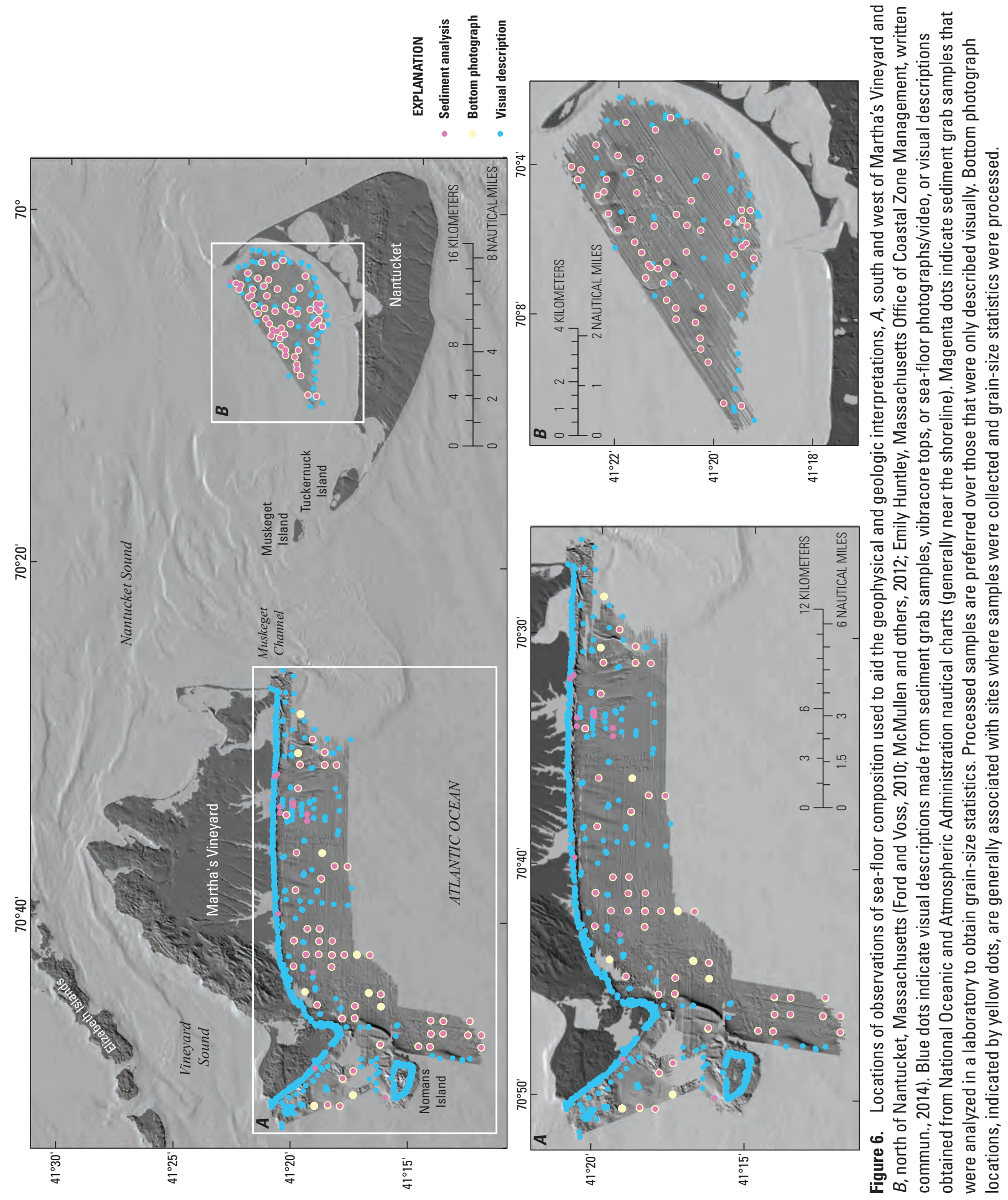




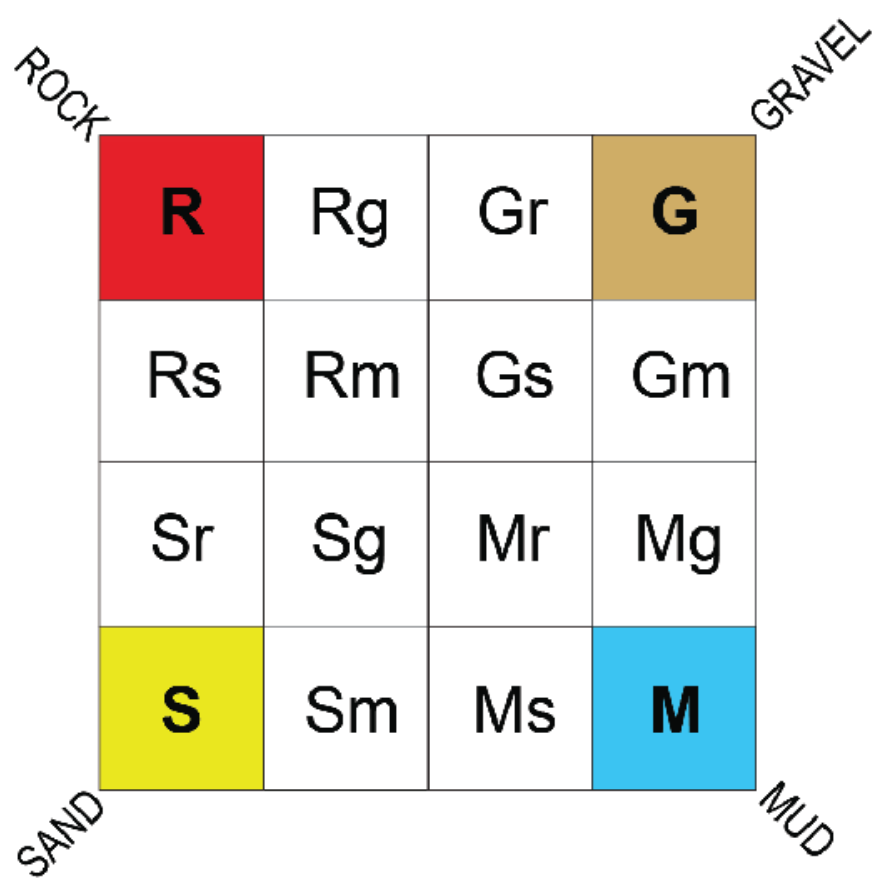

Figure 7. Barnhardt and others (1998) bottom-type classification based on four basic sediment units: rock (R), gravel $(G)$, sand $(S)$, and mud (M). Twelve additional two-part units represent combinations of the four basic units. In the two-part units, the primary texture (greater than 50 percent of the area) is given an uppercase letter, and the secondary texture (less than 50 percent of the area) is given a lowercase letter. Only the uppercase letter is used for areas where more than 90 percent of the texture is represented by one basic sediment unit. Figure is modified from Barnhardt and others (1998).

\section{Physiographic Zones}

Based on geologic maps produced for the western Gulf of Maine (Kelley and Belknap, 1991; Kelley and others, 1996; Barnhardt and others, 2006, 2009), and western Massachusetts Bay, the Merrimack Embayment, Cape Cod Bay, Buzzards Bay, Vineyard Sound, and western Nantucket Sound (Pendleton and others, 2013, 2015; Foster and others, 2015; Baldwin and others, 2016), the sea floor in the Martha's Vineyard and
Nantucket sites was divided into physiographic zones, which are delineated on the basis of sea-floor morphology and dominant sediment texture. Physiographic zone mapping allows for efficient characterization of large areas by using a variety of data sources that separately may not provide full sea-floor coverage. The zones were defined qualitatively in ArcGIS by using the same data sources and digitization techniques used to derive sediment texture and distribution.

\section{Results}

\section{Seismic Stratigraphy and Geologic Interpretation}

Four primary seismic stratigraphic units and three major unconformities were interpreted within the seismic survey area (figs. 5 and 9-14). Interpreted seismic profiles (figs. 10, 13, and 14) illustrate the typical geometry of the seismic units and unconformities throughout the Martha's Vineyard and Nantucket sites. Figure 12 contains interpreted geologic cross sections for one area north of Nantucket and two areas within the Martha's Vineyard study site. Figure 15 contains the surficial geologic map derived from mapping the areal extents of geologic unit outcrops on the sea floor. Correlations between our geologic interpretations, which are modified from Foster and others (2015) and Baldwin and others (2016), and those of O'Hara and Oldale $(1980,1987)$ for eastern Rhode Island Sound, Vineyard Sound, and western Nantucket Sound are summarized in figure 9. Our interpretations of the seismic stratigraphy generally agree with the previous studies (O'Hara and Oldale, 1980, 1987) where there is overlap. The higher density and spatial resolution of the new data allowed us to build on the previous interpretations and provide more detailed surficial and shallow subsurface geologic maps than previously available. However, the newly acquired chirp data did not provide adequate penetration for reliable mapping of the deep Pleistocene and pre-Quaternary units; therefore, discussion of the deeper stratigraphy mostly relies on previous interpretations that were based on more widely spaced but more deeply penetrating boomer seismic data and vibracores.

Table 2. Confidence levels assigned to sediment texture and physiographic zone polygons on the basis of the data used in the interpretation.

[The spatial distribution of polygons and associated confidence levels are shown in figure 8. lidar, light detection and ranging]

\begin{tabular}{|c|c|c|c|c|c|c|}
\hline Confidence level & Bathymetry & $\begin{array}{c}\text { Acoustic } \\
\text { backscatter }\end{array}$ & $\begin{array}{l}\text { Seismic } \\
\text { reflection }\end{array}$ & $\begin{array}{c}\text { Sediment sample } \\
\text { (laboratory analysis) }\end{array}$ & $\begin{array}{c}\text { Sediment sample } \\
\text { (visual analysis) }\end{array}$ & $\begin{array}{c}\text { Bottom } \\
\text { photograph }\end{array}$ \\
\hline One (high) & Swath & Yes & Yes & Yes & Yes & Possible \\
\hline Three (high) & lidar & No & No & Yes & Yes & Possible \\
\hline Four (low) & lidar & No & No & No & Yes & Possible \\
\hline
\end{tabular}




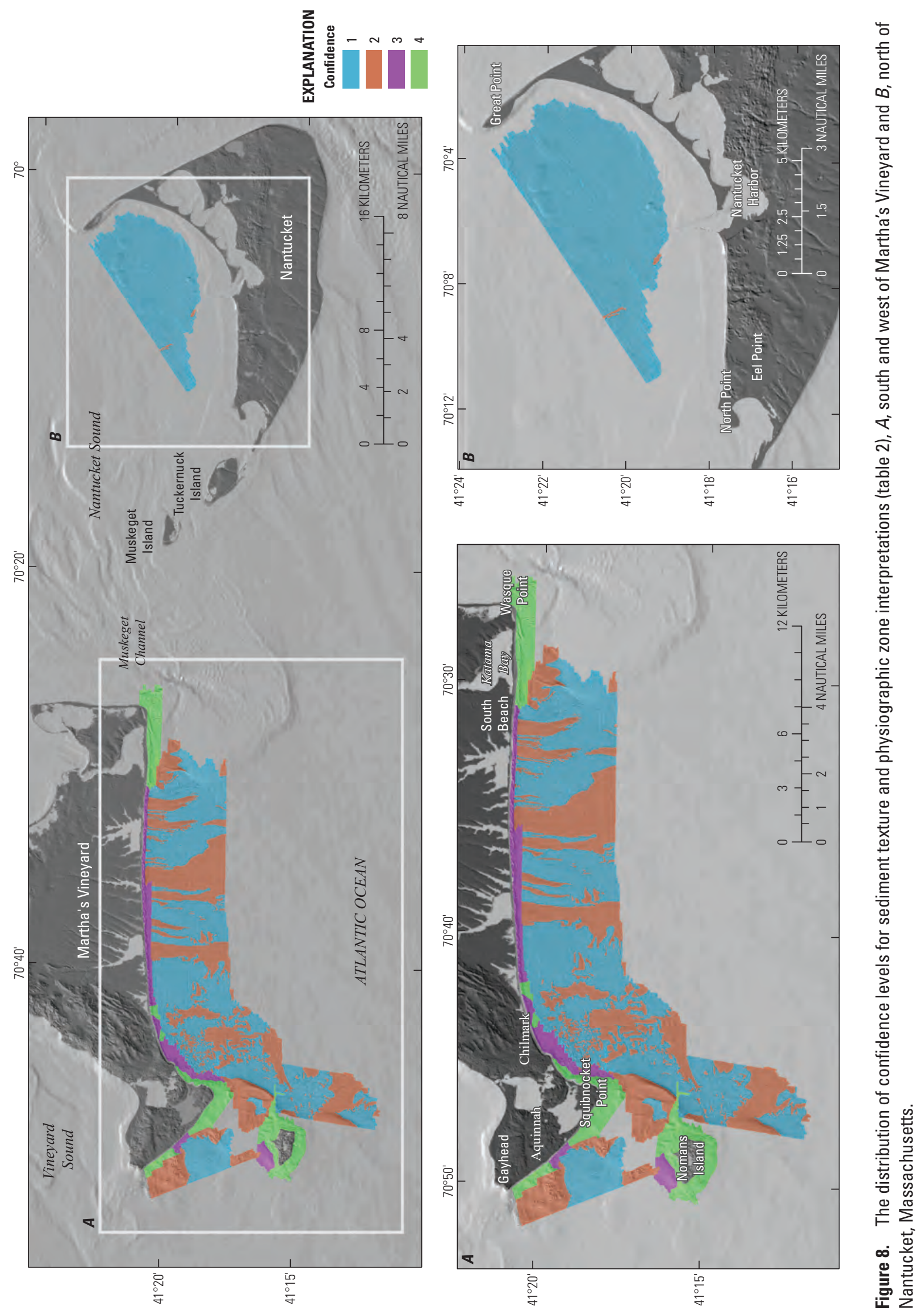




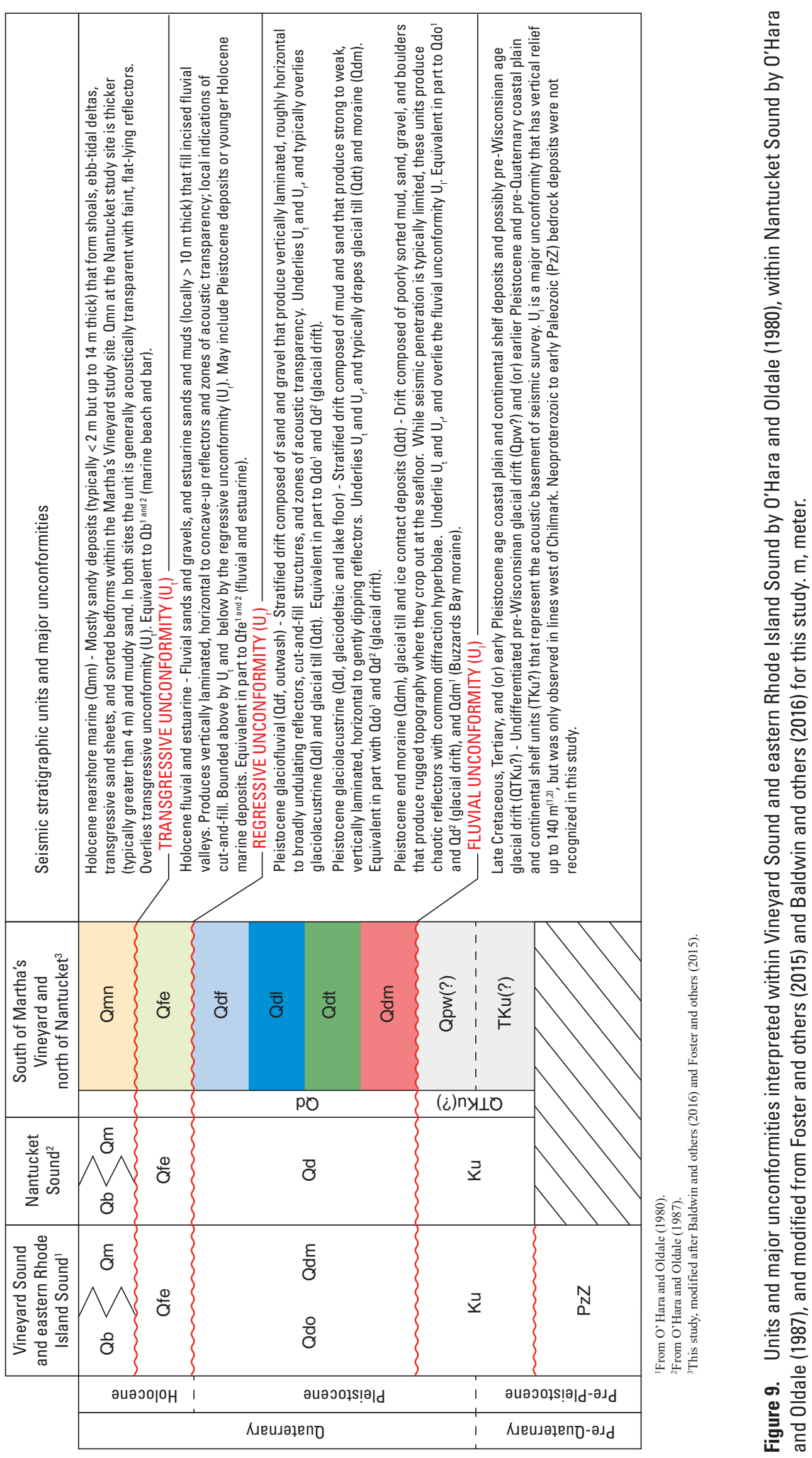



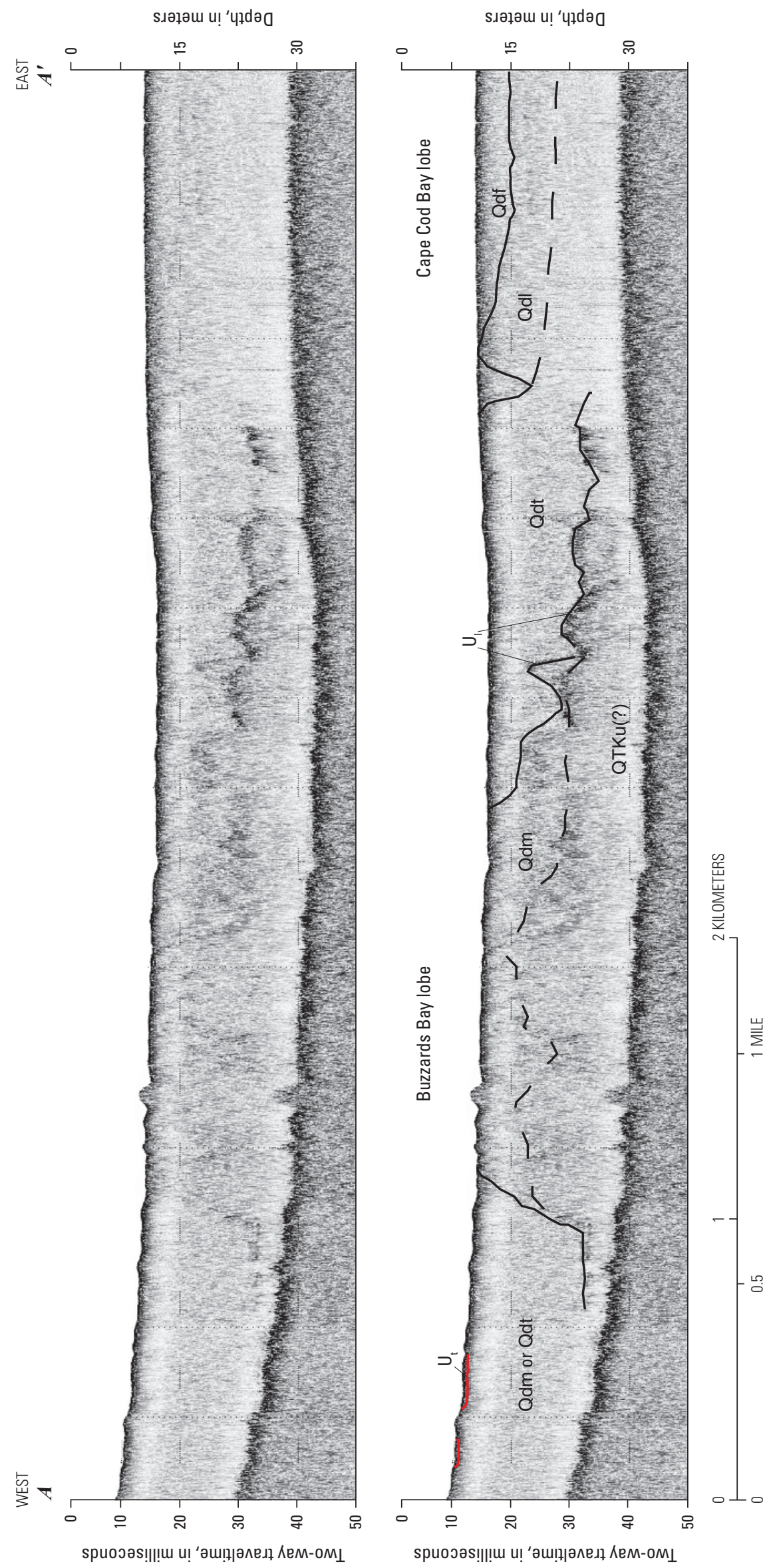

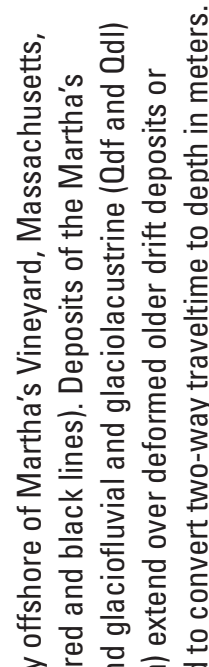

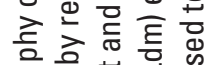

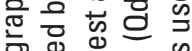

蒠离

离语吉 \%

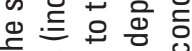

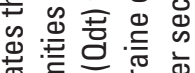

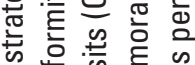

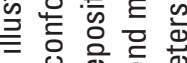

可宁

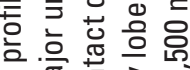

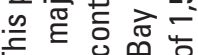

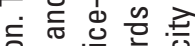

은 क⿻ 丿)

픙으ㅇㅝㅗㅇ

흔을 㐫志

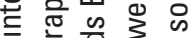

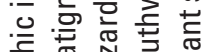

言离 N

흠

뜬

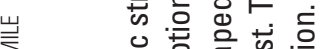

읕 흔흔

品

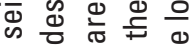

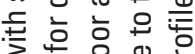

उ는은

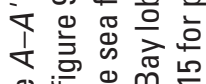

운

衣芯芯

든 눙흥

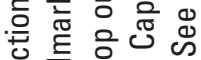

造 它岳

눈

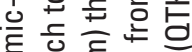

क

i $₫$ 응

을 矛. 동 웜

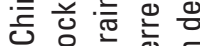

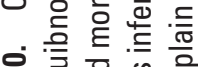

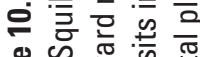

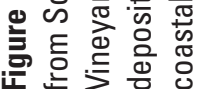



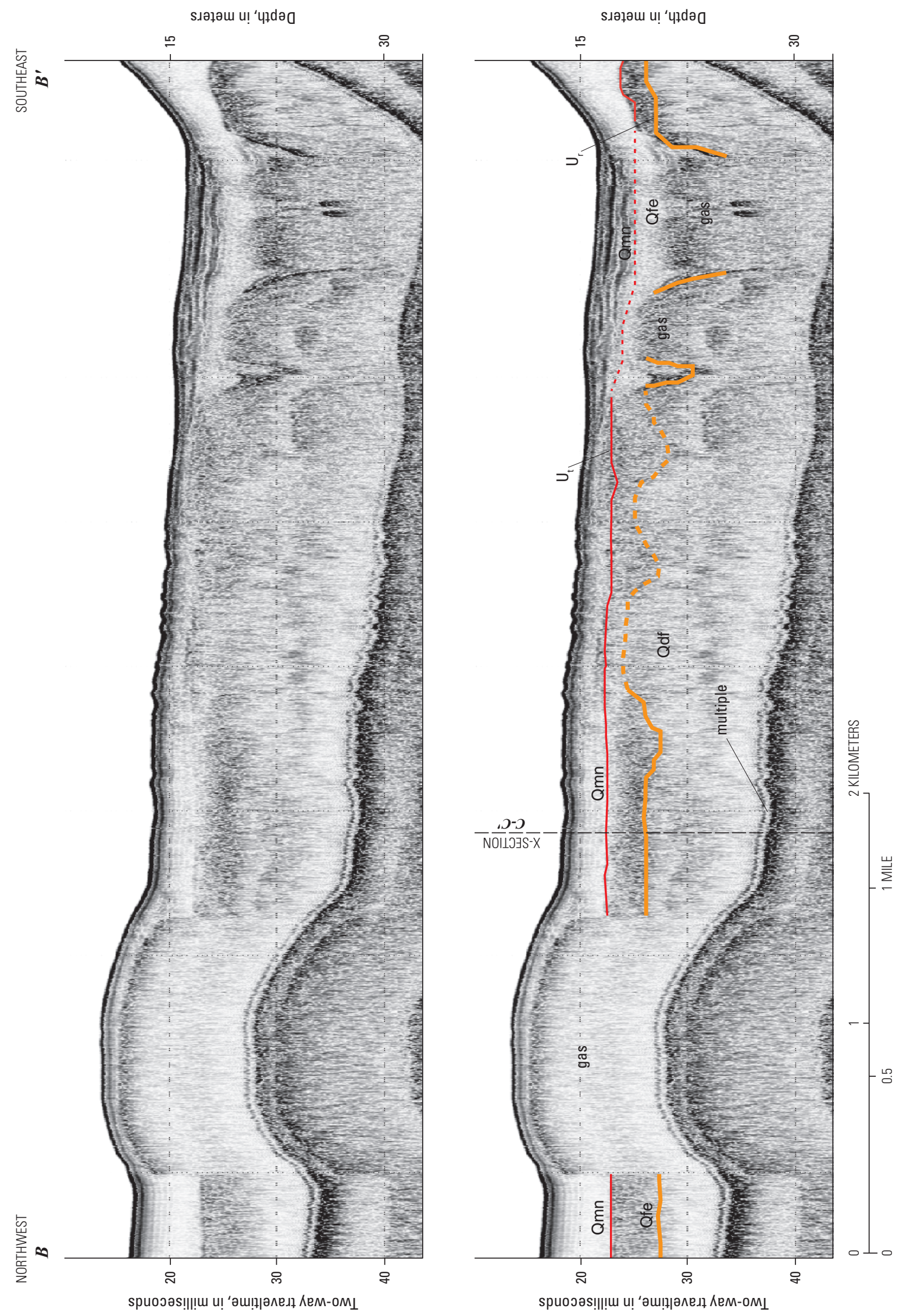

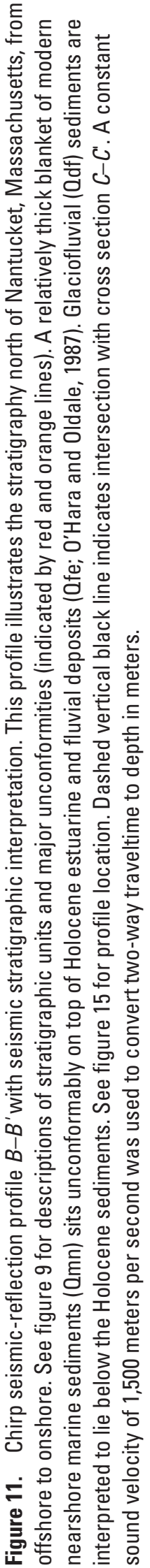



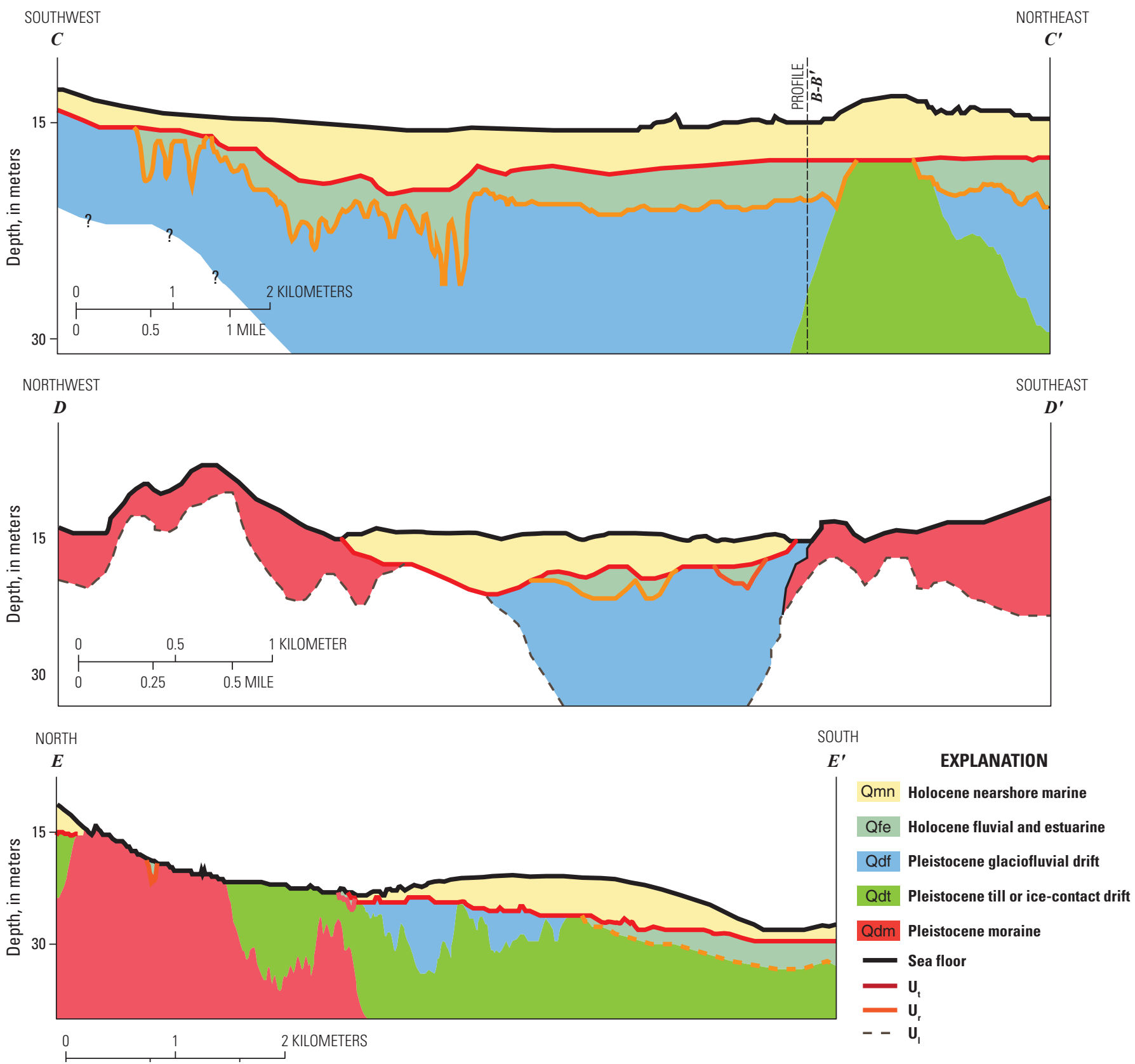

Figure 12. The general distributions and thicknesses of seismic stratigraphic units and major unconformities in the Martha's Vineyard and Nantucket, Massachusetts, study sites. The geologic sections $\left(C-C^{\prime}, D-D^{\prime}\right.$, and $\left.E-E^{\prime}\right)$ were produced from chirp seismic-reflection profile interpretations. See figure 9 for descriptions of stratigraphic units and unconformities. Geologic section locations are indicated on figure 15. The $U_{1}$ fluvial unconformity is a dashed line to denote that it is discontinuous and (or) inferred. 

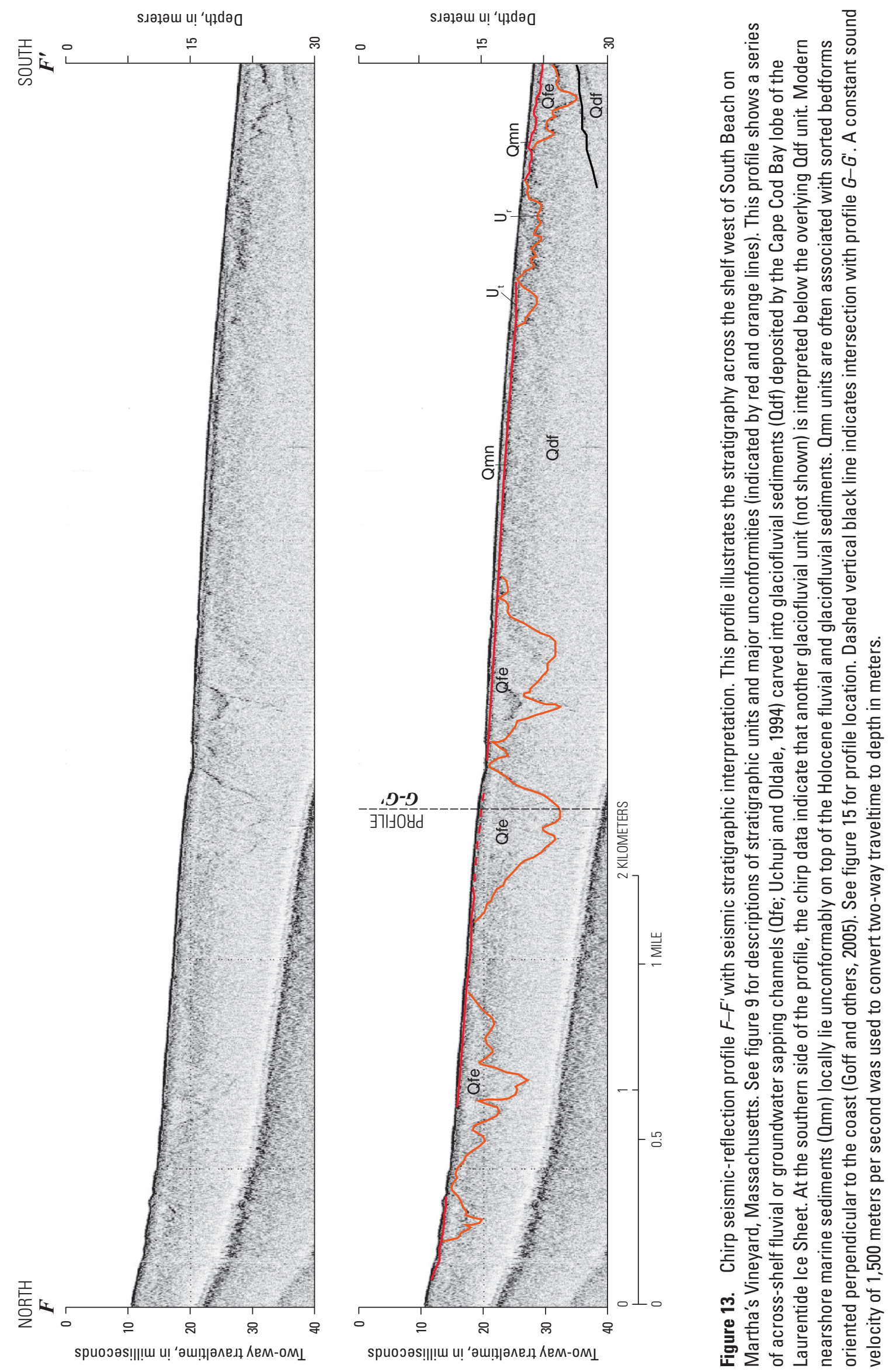

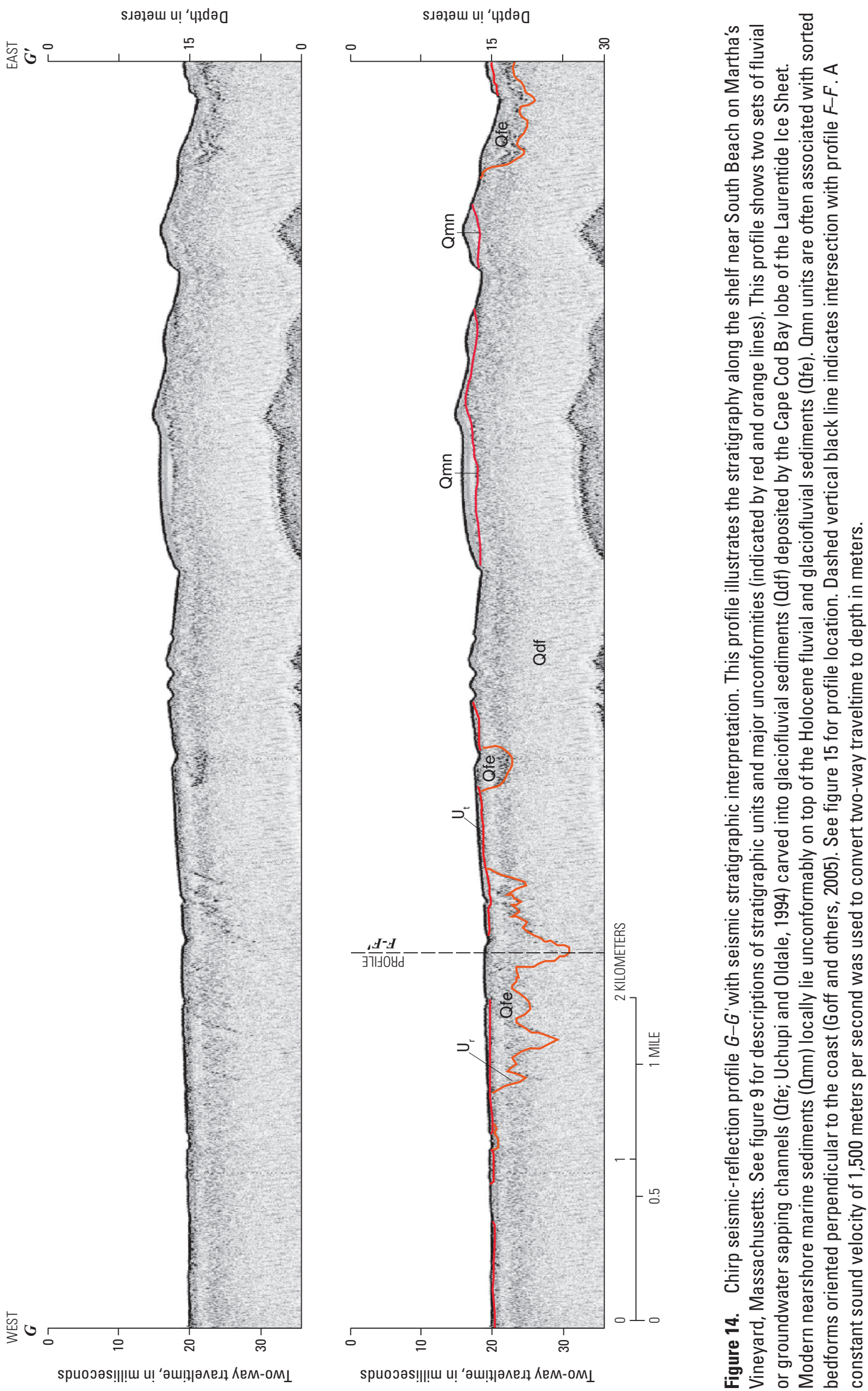

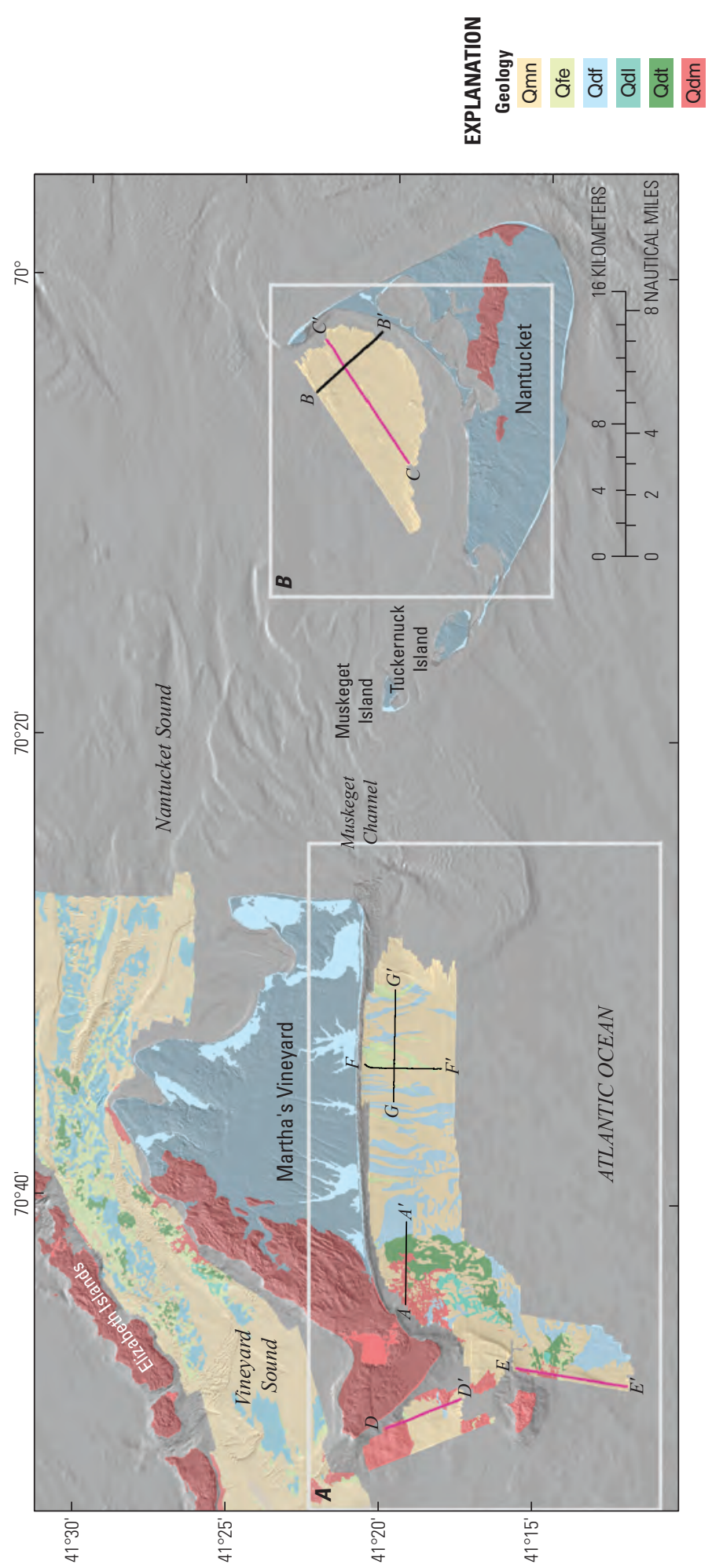
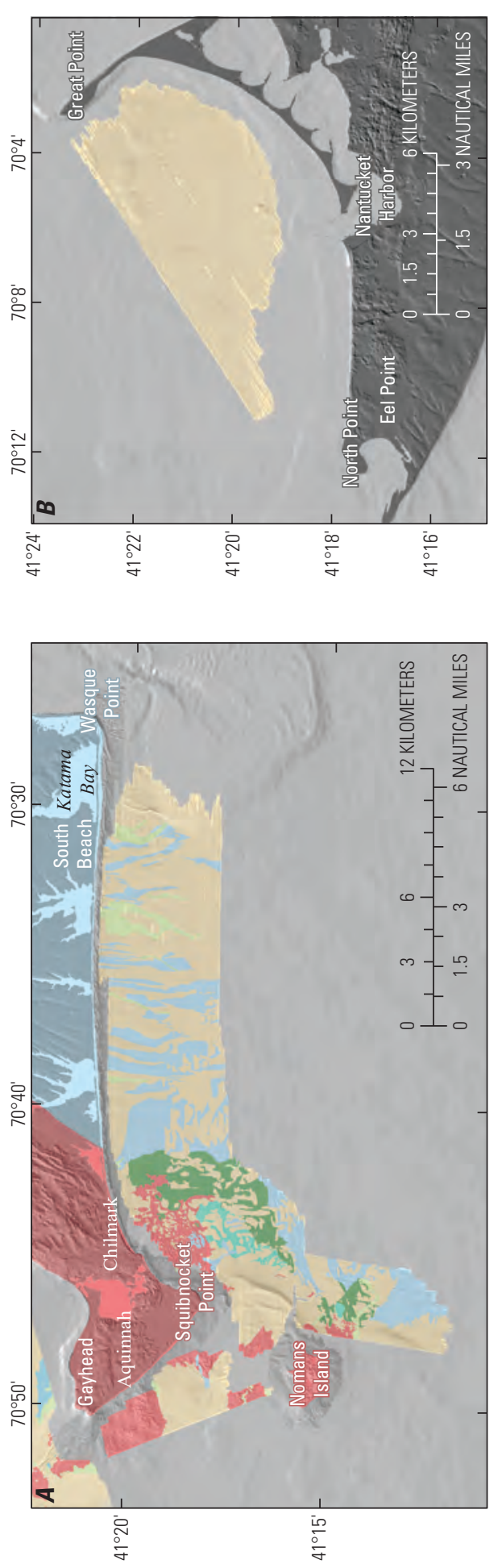

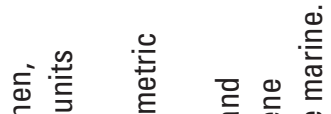

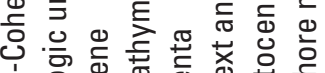

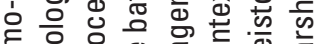

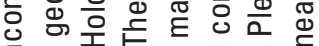

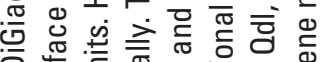

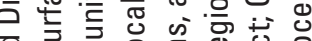

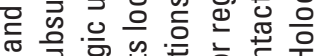
元 可 के 흔

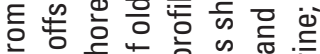

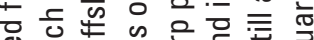
훅을 응 西

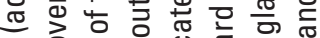

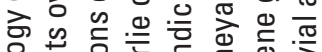
응 는 음 ब $\vec{x} \cdot \frac{2}{2}$ व ब

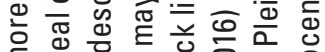

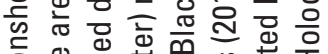
일

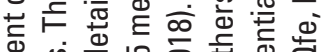
๗

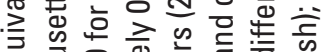
두ㅇㅝㅔ

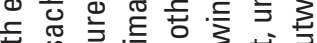

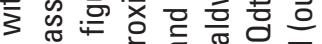

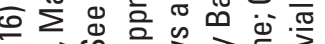

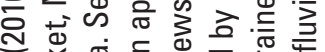

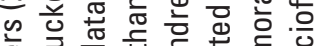

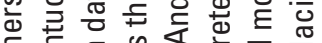

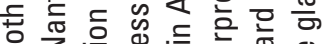

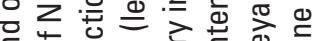
完

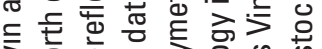
列

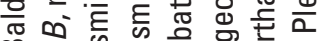

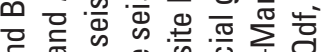
б

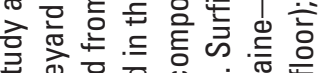
क्षे 잉

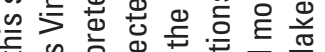
舟

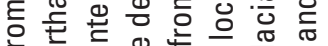
先

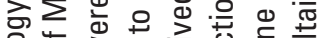
응 ब

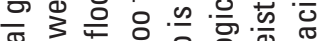

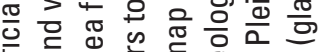
त

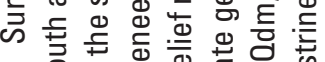

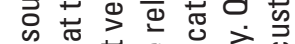

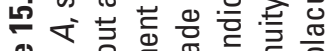

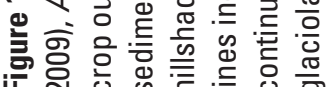


In ascending order, the four primary seismic stratigraphic units are (1) undifferentiated coastal plain and continental shelf deposits of Late Cretaceous(?), Tertiary(?), and (or) early Pleistocene(?) age and possibly glacial drift of late Pleistocene (pre-Wisconsinan?) age (QTKu?); (2) glacial drift of late Pleistocene (Wisconsinan) age (Qd); (3) postglacial fluvial and estuarine deposits of Holocene age (Qfe); and (4) Holocene postglacial marine deposits (Qmn). These are separated by three regional unconformities: $U_{1}, U_{r}$, and $U_{t}$ (fluvial, regressive, and transgressive, respectively, fig. 9). In addition, glacial drift deposits (Qd) are divided into subunits on the basis of seismic facies, stratigraphic position, and spatial distribution.

The lowermost stratigraphic unit mapped in previous studies within and adjacent to this area is of coastal plain and continental shelf deposits of Late Cretaceous(?), Tertiary(?), and (or) early Pleistocene(?) age and possibly glacial drift of pre-Wisconsinan(?) age (Woodsworth and Wigglesworth, 1934; Kaye, 1964a, b, 1980; Folger and others, 1978; Hall and others, 1980; O'Hara and Oldale, 1980, 1987; Oldale and O'Hara, 1984; Uchupi and Mulligan, 2006; Foster and others, 2015; Baldwin and others, 2016). However, because of the shallow penetration of the chirp seismic data used in this study, units below the unit inferred to be deposits of late Pleistocene (Wisconsinan) age (Qd) were not frequently observed. Qd is divided into four subunits - end moraine (Qdm), glacial till and ice-contact (Qdt), glaciolacustrine (Qdl), and glaciofluvial (Qdf) deposits - on the basis of their seismic facies, defined by internal reflections as well as their relative stratigraphic positions and spatial distributions. Qd subunits were generally recognized in chirp profiles as outcropping units, where they were present in the relatively shallow subsurface (less than about 40 milliseconds two-way traveltime), or when they were unobscured by the primary sea-floor multiple.

The end moraine (Qdm) and glacial till and ice-contact (Qdt) subunits produce similar seismic facies, consisting of irregular, high-amplitude surface reflections and chaotic and discontinuous internal reflections with common diffraction hyperbolae that often mask subunits (figs. 9 and 10). Chaotic reflections within Qdm and Qdt and hyperbolic diffractions where these units intersect the sea floor are interpreted as acoustic signatures of poorly sorted, relatively coarse drift and boulders. Qdm is specifically inferred to represent till associated with the Martha's Vineyard end moraine (fig. 10). Qdt units are present at the sea floor in discrete locations in the western part of the Martha's Vineyard site (fig. 15) and are interpreted to represent outcrops of supraglacial or subglacial stagnation till, lodgment till, or deformation till.

The glaciolacustrine (Qdl) and glaciofluvial (Qdf) subunits represent stratified drift of late Pleistocene age that was deposited by glacial meltwater. The glaciolacustrine seismic facies is characterized by vertically laminated, horizontal to gently dipping reflections of variable amplitude. Qdl reflections are undulatory where they conformably drape the irregular surfaces of Qdm or Qdt and where they have been deformed. The seismic signature of Qdl is interpreted to represent varved, relatively fine grained, glaciodeltaic or glaciolacustrine deposits. The glaciofluvial (Qdf) seismic facies is characterized by zones of acoustic transparency along the south shore of Martha's Vineyard, but less continuous units are present as undulatory, or gently to steeply dipping laminated reflections, chaotic and discontinuous reflections, or cut-andfill structures (figs. 10-13 and 14). Generally, seismic-reflection data penetration was not adequate for mapping the base of Qdf; however, Qdf is observed to overlie other Qd subunits locally, and its variable seismic character indicates a variety of outwash morphologies.

The medium-to high-amplitude, irregular to undulating seismic reflection $\mathrm{U}_{\mathrm{r}}$ (regressive) unconformity delineates the eroded upper surface of Qd (figs. 11, 13, and 14) and represents the regressive unconformity of late Wisconsinan to early Holocene age (fig. 16). The $U_{r}$ surface contains subsurface valleys that deepen progressively offshore from the drowned valleys of Martha's Vineyard and toward the eastern margin of the Nantucket site. These morphologies resulted through a combination of glacial lake drainage, meltwater fluvial erosion, and later fluvial erosion during the early Holocene. $U_{r}$ is a composite unconformity that merges with the $U_{t}$ (transgressive) unconformity outside of glaciofluvially eroded areas.

The remaining two primary stratigraphic units that overlie the Qd unit represent primarily Holocene fluvial and estuarine (Qfe) and nearshore marine (Qmn) deposits (figs. 9 and 17). Qfe is the lowermost of these deposits, and where present, it fills the deepest portions of the Martha's Vineyard valleys and the Nantucket Sound basin formed by $\mathrm{U}_{\mathrm{r}^{\prime}}$ Qfe produces seismic signatures that include laminated, horizontal to concave-up reflections, cut-and-fill structures, and zones of near acoustic transparency (figs. 11, 13, and 14). Qfe units are interpreted to consist of late Pleistocene and Holocene fluvial deposits, as well as younger Holocene estuarine fill related to marine transgression. Qfe deposits are thickest where they form the youngest fills within the major channel trunks in the Pleistocene drainage network (figs. 11 and 17). In some locations north of Nantucket, biogenic gas, presumably produced in the organic-matter-rich estuarine sections of Qfe, attenuated the seismic signal and prevented interpretation of underlying units.

Seismic reflector $U_{t}$, a medium-amplitude, mostly flatlying, and continuous reflector, is interpreted to represent the Holocene marine transgressive unconformity and generally defines the boundary between Holocene marine (Qmn) deposits and older underlying units. $U_{t}$ is a composite unconformity that merges with $U_{r}$ wherever Qfe is absent (figs. 11 and 13).

The Holocene marine (Qm) seismic facies is characterized by medium- to low-amplitude, flat-lying to steeply dipping, laminated reflections and zones of acoustic transparency (figs. 11, 13, and 14). Qmn deposits are composed primarily of sand and some gravel and form the beaches and bars along the shorelines, as well as shoals, sand ridges and sheets, and smaller bedforms on the sea floor (figs. 15 and 17). 


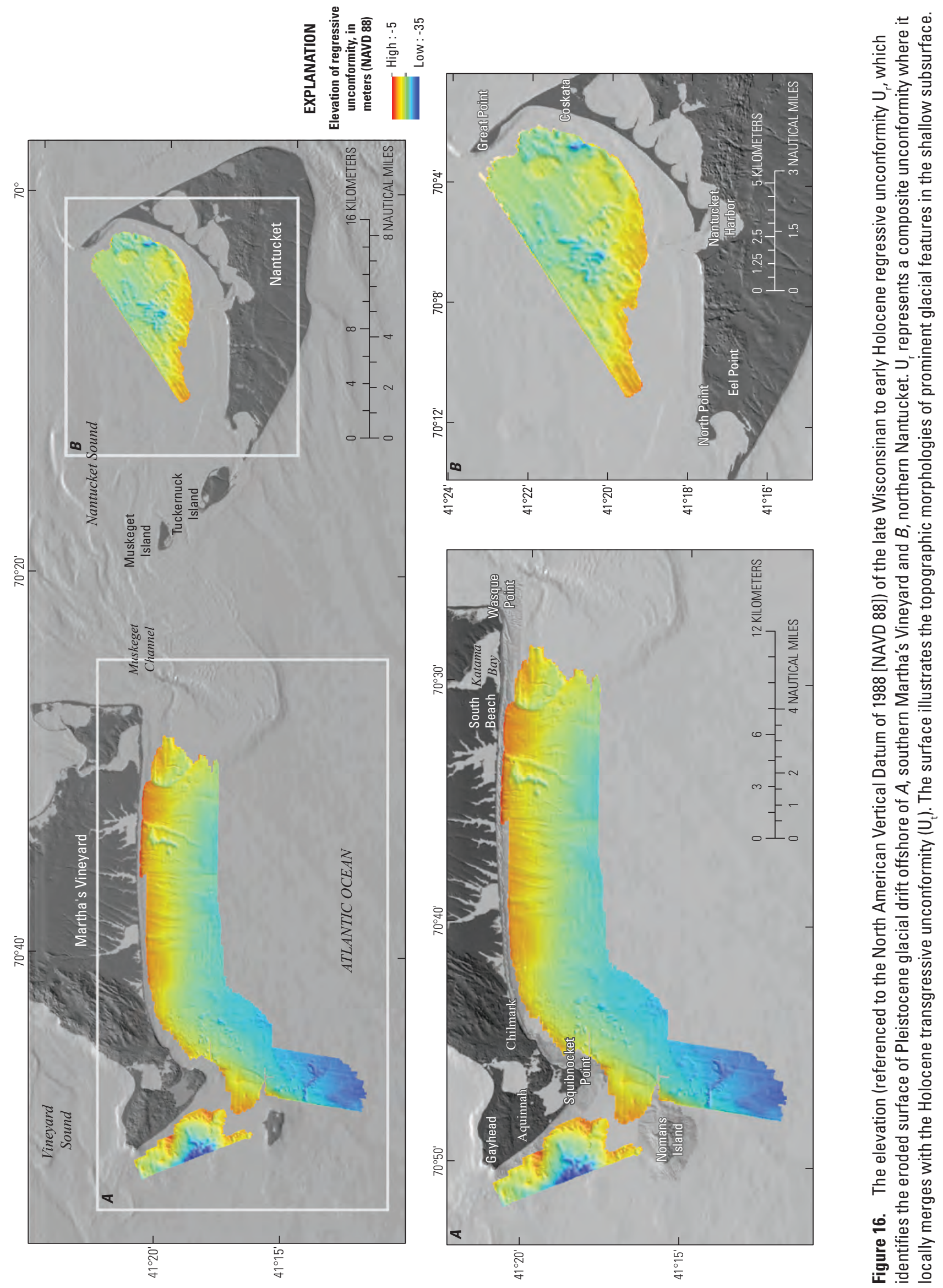




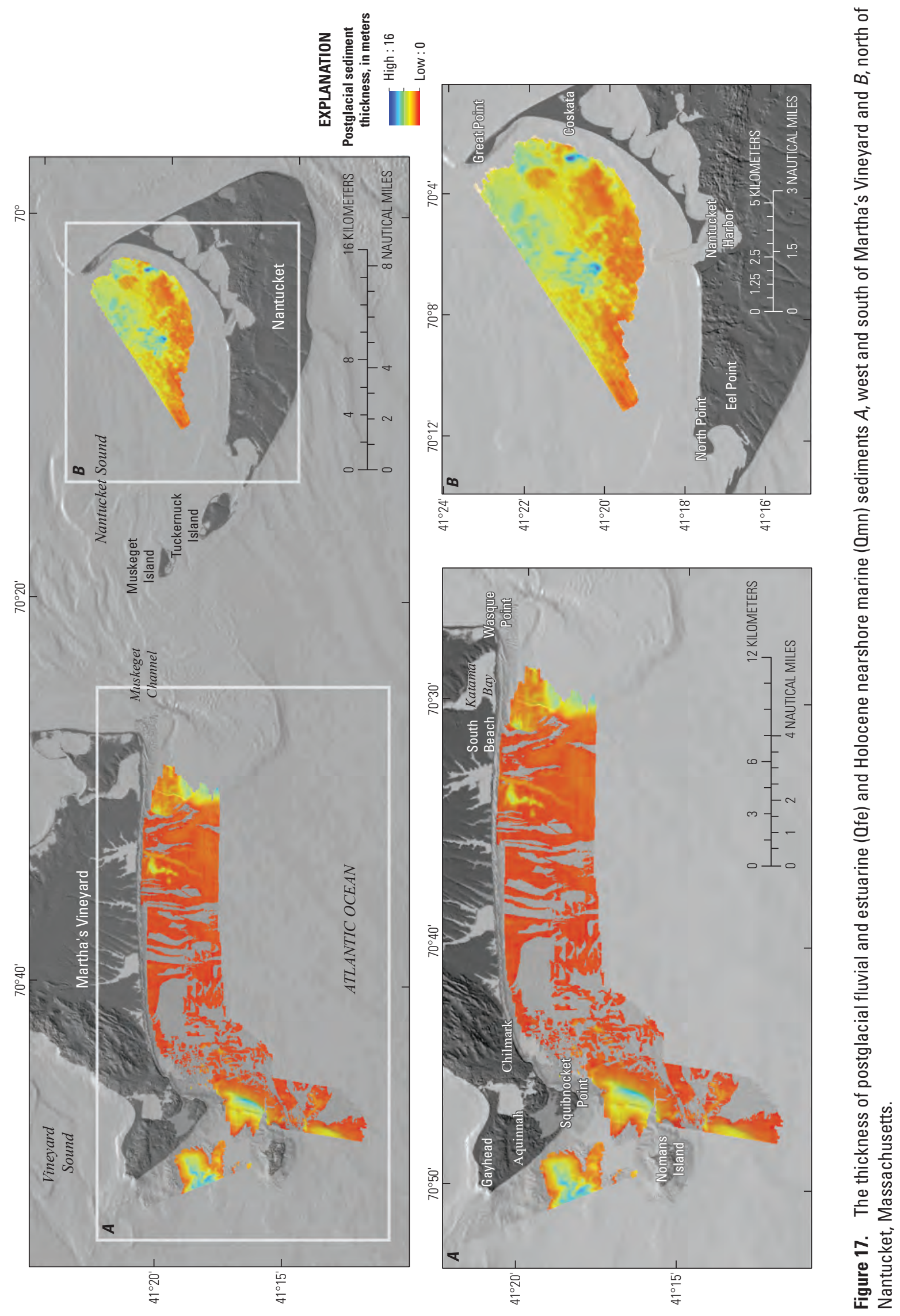




\section{Sediment Texture and Distribution}

Sediment texture and distribution were mapped for more than $265 \mathrm{~km}^{2}$ of the inner shelf (fig. 18) by using the Barnhardt and others (1998) classification (fig. 7). The data were interpreted at scales ranging from 1:8,000 to $1: 25,000$, depending on the resolution of the source geophysical grids and the density of the sample data.

Sediments within the study area represent nearly all particle sizes. Sediment texture ranges from muddy sands primarily north of Nantucket to pebbles, cobbles, and boulders where tills and moraine deposits are exposed at the sea floor (figs. 15 and 18-20). Both coarse- and fine-grained sediment exist in all water depths; however, rocky textures are generally most prevalent along the nearshore margin of southwestern Martha's Vineyard (figs. 18 and 19). Rocky textures are least concentrated east of Chilmark and north of Nantucket (figs. 18-20). Overall, the distribution of samples in the texture database for the study area is 62 percent sand, 33 percent mud, and 5 percent gravel by weight.

Sand (greater than $0.062 \mathrm{~mm}$ to $2 \mathrm{~mm}$ ) is the dominant bottom sediment type within the study area and is interpreted to cover 92 percent of the sea floor by area (fig. 18). Sand is most extensive east of Chilmark. Muddy sediments, which include silt- and clay-size particles less than $0.062 \mathrm{~mm}$ in diameter, cover 1 percent of the sea floor by area within the Martha's Vineyard study site but are present in the Nantucket site in nearly 70 percent of the sea floor by area. Gravel or particles greater than $2 \mathrm{~mm}$ but less than $64 \mathrm{~mm}$ ( -1 to $-6 \mathrm{phi}$ ) in diameter are interpreted to be the primary sediment cover in less than 1 percent of the sea floor. Primarily rocky areas are interpreted to cover about 7 percent of the sea floor by area and are most prevalent adjacent to morainal headland deposits on the western and southwestern sides of Martha's Vineyard (figs. 15, 18, and 19). Photographs document the presence of gravel and cobble in rocky areas where sediment sampling devices were unable to recover large-diameter particles, suggesting that gravel and rock are underrepresented in sediment sample data in this area.

\section{Physiographic Zones}

The areal distribution of physiographic zones in the offshore part of the study area $\left(265 \mathrm{~km}^{2}\right)$ was interpreted at a scale ranging from $1: 8,000$ to $1: 25,000$, depending on the resolution of the source geophysical grids (fig. 21).

Rocky zones are rugged areas, which often exhibit high bathymetric relief, ranging from ridges to relatively flat, gravel-covered plains with boulders several meters in diameter. Although coarse-grained sediments are locally present in all physiographic zones, they dominate the sea floor in rocky zones. Rocky zones are common from Gay Head to Chilmark
(12 percent of the sea floor by area) but are absent throughout the rest of the Martha's Vineyard study site and north of Nantucket.

Zones of coastal embayments include much of the study area north of Nantucket. Coastal embayments cover $38 \mathrm{~km}^{2}$, or about 14 percent, of the study area.

Ebb-tidal deltas are present on the eastern edge of the Martha's Vineyard site, where the western edge of the large Muskeget Channel ebb-tidal delta can be identified in the geophysical data. Ebb-tidal delta zones compose just less than 2.5 percent of the sea floor within the entire study area.

Hard-bottom plains tend to have low bathymetric relief and a coarse sediment texture consisting of primarily gravel, sand, and rock. Hard-bottom plains account for about 1.5 percent of the sea floor and are on the western side of Martha's Vineyard, adjacent to rocky zones associated with morainal deposits.

Nearshore ramps are areas of gently sloping sea floor with generally shore-parallel bathymetric contours. These zones are primarily interpreted as sand-rich sediment, although small exposures of cobbles and boulders locally crop out on the sea floor. Nearshore ramps are the primary physiographic zone on the south side of Martha's Vineyard, east of Chilmark. Within the entire study area (Martha's Vineyard and Nantucket), nearshore ramps are the most abundant physiographic zone, accounting for nearly half of the sea floor by area, which is likely a result of the substantial amount of open-ocean inner shelf offshore of southern Martha's Vineyard (fig. 21).

Shelf valleys are elongate depressions that extend offshore, often perpendicular to the trend of the coastline, and slope gently seaward. Shelf valleys represent about 11 percent of the study area in total, but they are absent east of Chilmark. They likely existed there as well but may have been reworked into a broad sand sheet during transgression. These zones are interpreted to have formed by fluvial erosion during periods of lower-than-present sea level and are most commonly dominated by sandy textures.

Shoal/sand waves are sea-floor zones dominated by linear to sinuous bedforms primarily composed of sandy sediments that have been reworked from adjacent glacial deposits by wave and tidal currents. Water depths range from approximately 10 to $30 \mathrm{~m}$. Shell zones are areas that are nearly completely covered by carbonate shells. High densities of slipper shells (Crepidula fornicata) were recognized within areas of sea floor north of Nantucket. Shell zones (figs. 20 and 21) and sand waves account for just over 5 percent of the sea floor by area. Foster and others (2015), Ackerman and others (2016), and Baldwin and others (2016) recognized similar accumulations of Crepidula in the central Buzzards Bay basin and western Nantucket Sound. 


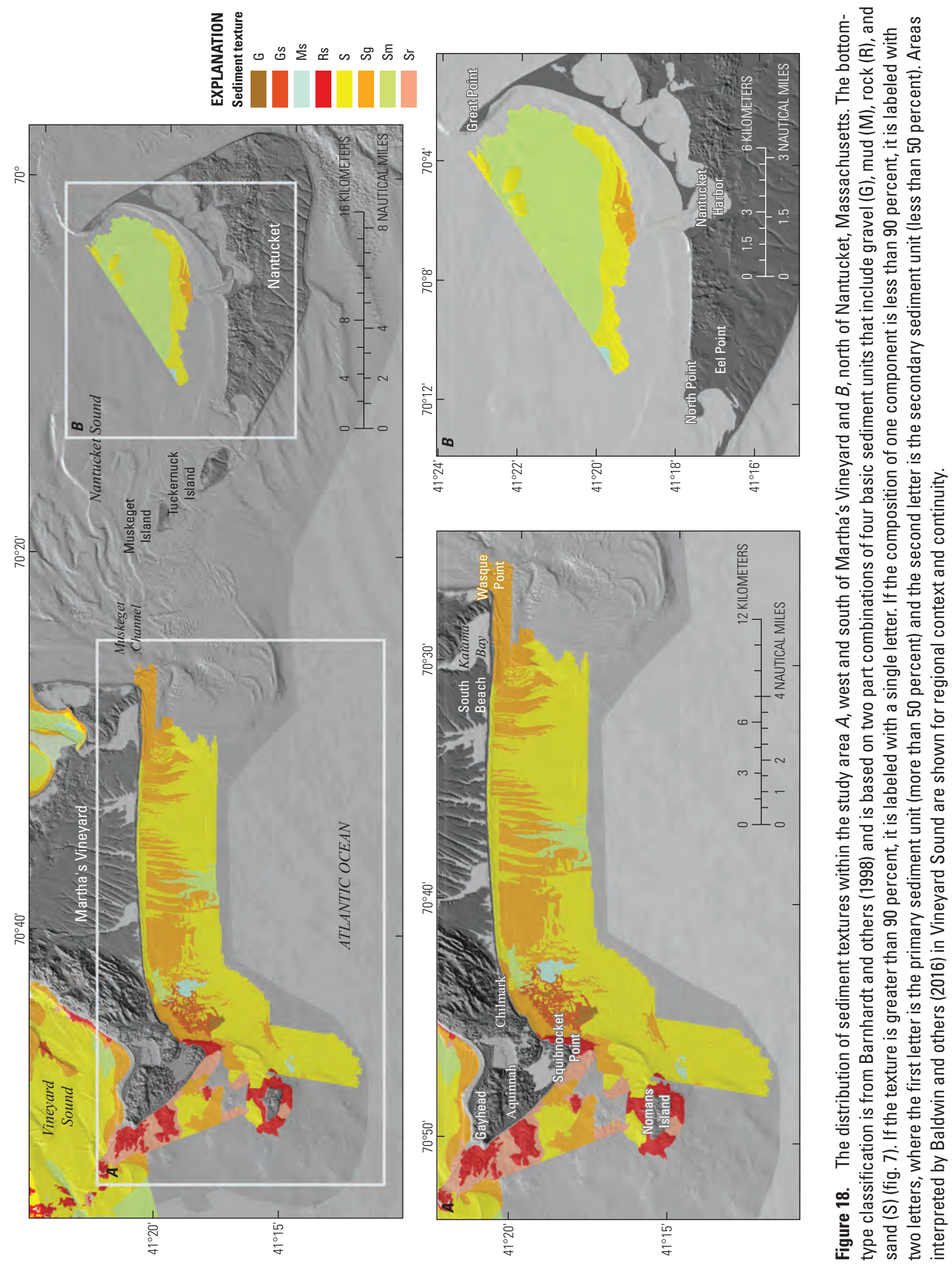




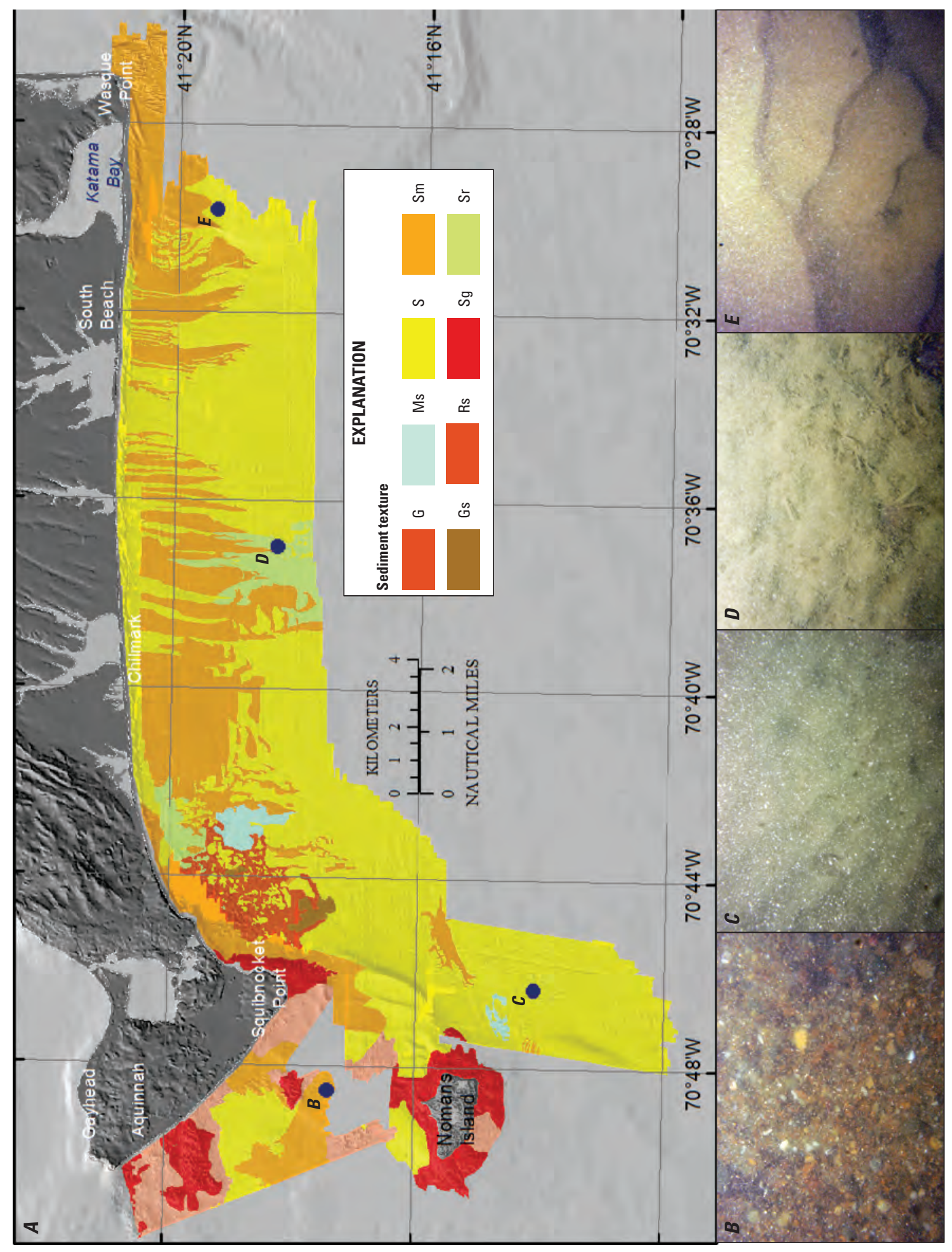

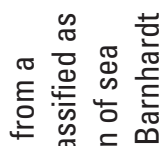

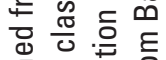

禀 焉

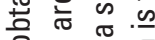

응 드음

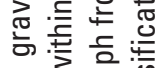

요유

बे

동 흥음 일

is

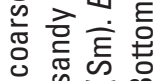

¿

등 产

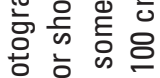

듬은 돈운

$\infty$ 舟 8

उं

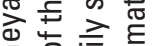

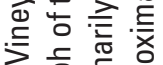

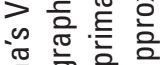

준흥

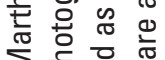

$\sum \frac{\pi}{0}$ 후

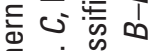

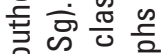

कि 흥

돋

휴 훙

क्ष

\& 5 is

క⿺辶一

o s

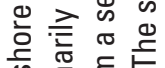

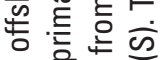

क is 등무

证要

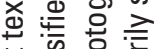

늫

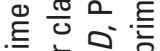

के

ष

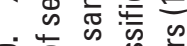

문

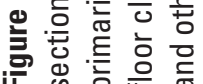




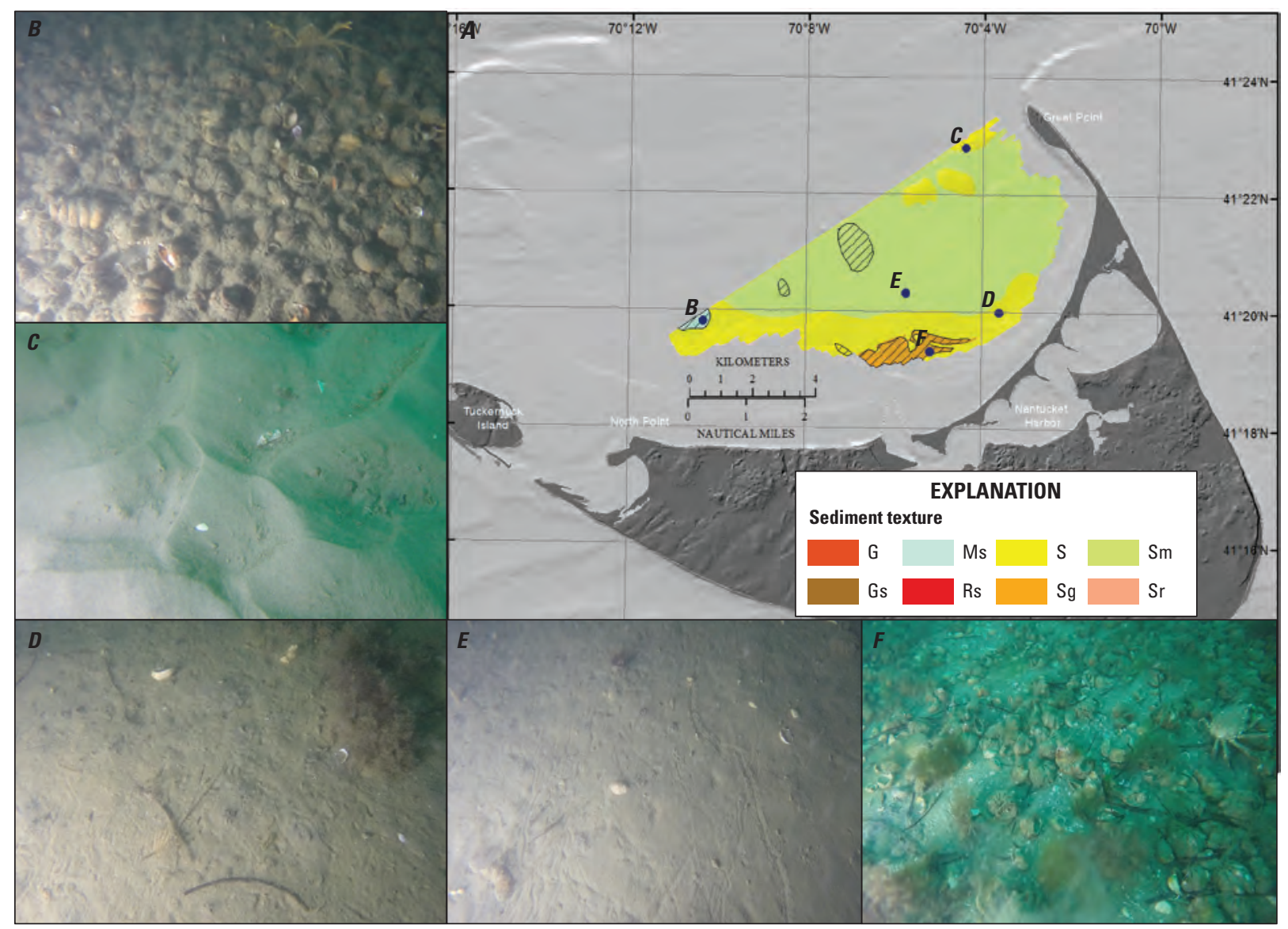

Figure 20. A, Sediment textures offshore of northern Nantucket. B, Photograph of the seafloor covered by highly concentrated Crepidula fornicata. The sediment below the shells is classified as primarily sand with mud (Sm). $C$, Photograph of the sea floor showing sandy sediment within an area classified as primarily sand (S). D, Photograph from a section of sea floor classified as primarily sand (S). E, Photograph from a section of sea floor classified as primarily sand with some mud $(\mathrm{Sm})$. F, Photograph from a section of sea floor classified as primarily sand with gravel $(\mathrm{Sg})$ that is also blanketed with a fairly dense covering of Crepidula fornicata. Shell zones are outlined with cross-hatching. Bottomtype classification is from Barnhardt and others (1998). 


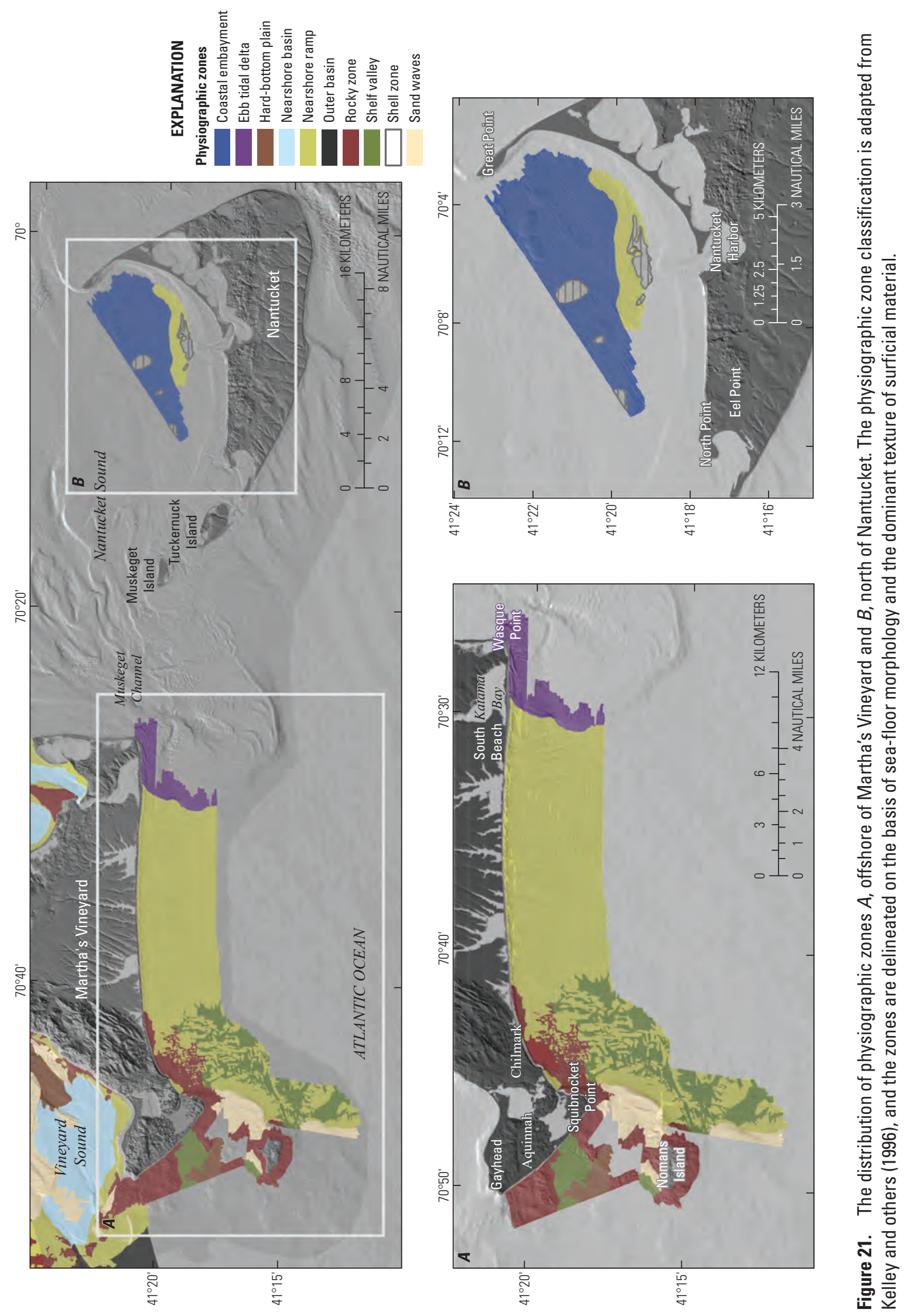




\section{Discussion}

\section{Synthesis of Maps}

Three of the four primary stratigraphic units (fig. 9) crop out at the sea floor in the study area (fig. 15), and the interpretations of surficial sediment texture (fig. 18) and physiographic zones (fig. 21) are closely related to the distribution of these units. Surficial geologic units may not directly correspond with surficial sediment units because geologic units may be buried beneath a sediment layer too thin to detect in the seismic data (less than about $0.5 \mathrm{~m}$ ), or the outcropping unit may be winnowed or reworked at the sea floor.

No undifferentiated coastal plain and continental shelf deposits of Late Cretaceous(?), Tertiary(?), and (or) early Pleistocene(?) age and possibly glacial drift of late Pleistocene (pre-Wisconsinan?) age (QTKu?) were interpreted to crop out at the surface in the geophysical and geologic data. Small, local areas may crop out but cannot be differentiated from Pleistocene end moraine deposits (Qdm) in the chirp data because of a lack of penetration, especially in the 2011 dataset (Andrews and others, 2014). Thrusted and deformed portions of QTKu(?) are known to compose much of the terminal moraine complex along the western margin of Martha's Vineyard, are exposed along the shore in the Aquinnah cliffs, and extend west and south beneath the shallow subsurface (Woodsworth and Wigglesworth, 1934; Kaye, 1964a, b; O'Hara and Oldale 1980, 1987; Oldale and O'Hara, 1984). Outcrops of Qdm associated with the Martha's Vineyard moraine are mapped at the sea floor west and southwest of Martha's Vineyard and are interpreted to cover underlying QTKu(?) units. Where discontinuous reflectors of QTKu(?) units are identified and interpreted in the chirp data, they are commonly as shallow as $5 \mathrm{~m}$ below the sea floor. The presence of boulders and cobble-sized clasts in bottom photos from Qdm outcrops suggests that these units are associated with $\mathrm{Rg}, \mathrm{Rs}, \mathrm{Sr}$, and G surficial sediment textures and rocky physiographic zones (figs. 15, 18, and 21).

Late Pleistocene glacial till and ice-contact (Qdt) outcrops are present mostly in the southwestern section of the Martha's Vineyard study site (fig. 15), associated with the Martha's Vineyard moraine. These outcrops contain boulders and cobbles and represent sea-floor exposures of ice-contact sediments that are buried by younger sediment in adjacent areas. Qdt crops out adjacent to Qdm units offshore of Chilmark, is interpreted here as stagnation till, and is locally covered by late Pleistocene glaciolacustrine (Qdl), glaciofluvial (Qdf), or Holocene nearshore marine (Qmn) deposits (figs. 10 and 15). Qdt is primarily associated with Gs, Sg, and $\mathrm{S}$ surficial sediment textures and rocky zones and nearshore ramp physiographic zones (figs. 15, 18, and 21).

Glaciolacustrine deposits (Qdl) are typically buried by younger units but are exposed at the sea floor and fill depressions between Qdm and Qdt deposits just offshore of Squibnocket Point (fig. 15). Depressions filled with Qdl units may have been created by the melting of blocks of stagnant ice within or on top of the till or outwash near the ice margin. Glaciofluvial outcrops of late Pleistocene age (Qdf) are extensive offshore beyond the extents of Qdm and Qdt and east of Chilmark in the Martha's Vineyard study site. The Qdf sediments are interpreted to be primarily associated with Cape Cod Bay ice lobe outwash deposits. Qdf and Qdl are in most places associated with $\mathrm{S}$ or $\mathrm{Sg}$ textures and with nearshore ramps and shelf valley physiographic zones (figs. 15, 18, and 21).

Holocene fluvial and estuarine (Qfe) outcrops in the Martha's Vineyard study site are generally exposed in sublinear to sinuous patterns incising outcrops of Qdf, Qdt, or Qdm (fig. 15). Several drainage channels, some of which may also be associated with groundwater sapping valleys (Uchupi and Oldale, 1994), incise the outwash plain offshore and east of Chilmark to Katama Bay (figs. 16 and 17). Qfe is primarily associated with the $\mathrm{Sg}$ and $\mathrm{S}$ surficial sediment types and the nearshore ramp physiographic zone (figs. 15, 18, and 21).

A Holocene nearshore marine $(\mathrm{Qmn})$ unit overlies parts of each of the other units throughout the study area of Martha's Vineyard and blankets the entire study site of Nantucket (fig. 15). Qmn is composed of fine-grained sediments that we interpret to be derived from the erosion, reworking, and winnowing of the older underlying glacial and postglacial sediments. In the Martha's Vineyard study area, Qmn is relatively thin ( $2 \mathrm{~m}$ or less) across much of the shelf but is quite thick where it is associated with two large sand shoals north and south of Nomans Island. Qmn is also thin (less than $2 \mathrm{~m}$ ) along the western side of the Nantucket study site, where glaciofluvial material is exposed at the surface on Tuckernuck Island and east nearly to Nantucket Harbor (Oldale and Barlow, 1986), but Qmn thickens toward Great Point. Qmn units are primarily sandy, coinciding with $\mathrm{S}, \mathrm{Sg}$, and Sm surficial sediment types (figs. 15 and 18). These units form the sandy inner shelf areas of nearshore ramps, coastal embayments, and the modern mobile bedforms of ebb-tidal deltas, shell zones, and shoal/sand wave zones (figs. 15 and 21).

\section{Geologic History and Framework}

Interpretation of the geologic framework and seismic stratigraphy offshore of Martha's Vineyard and north of Nantucket was fundamental in developing a foundation for the surficial maps presented here, and this interpretation informed our understanding of the late Pleistocene to Holocene deposition history of the area. Our interpretations of the geologic framework west of Martha's Vineyard and north of Nantucket are compatible with those of O'Hara and Oldale $(1980,1987)$, respectively, and our interpretation of the geologic framework for the inner continental shelf along the south shore of Martha's Vineyard is new. The geologic framework presented here as a series of interpretive maps describes the glacial and postglacial depositional history that resulted from the retreat of the late Wisconsinan Buzzards Bay and Cape Cod Bay ice lobes and subsequent Holocene marine transgression. These dense, high-resolution data and mapping products refine our 
Shallow Geology, Sea-Floor Texture, and Physiographic Zones Offshore Martha's Vineyard and Nantucket, Mass.

understanding of the shallow geologic framework offshore of Martha's Vineyard and north of Nantucket and foster new insights about regional depositional history and the relations between near-surface geologic units and sea-floor morphology and composition.

\section{Glacial Recession}

This mapping describes the interaction between the icecontact material at the margin of the Buzzards Bay ice lobe and the outwash plains of the Cape Cod Bay ice lobe along the south and west coast of Martha's Vineyard and also describes the retreat of the Cape Cod Bay ice lobe from the terminal moraine on Nantucket. Foster and others (2015) and Baldwin and others (2016) presented a suite of geologic maps and interpretations, equivalent to those presented here, that describe the stepwise recession of the Cape Cod Bay and Buzzards Bay ice lobes from the Martha's Vineyard end moraine through Vineyard and Nantucket Sounds and Buzzards Bay, respectively. They described a sequence of proglacial lacustrine, deltaic, and fluvial outwash units that filled basins dammed by icemarginal ridges that were subsequently incised by a meltwater drainage network. The interpretations presented here build on these descriptions of the retreat of the Buzzards Bay and Cape Cod Bay ice lobes from an earlier time at their maximum positions (Uchupi and others, 1996; Oldale, 2001; Balco and others, 2002; Uchupi and Mulligan, 2006; Balco, 2011).

The shallow stratigraphy of the inner continental shelf offshore of Aquinnah on the western side of Martha's Vineyard is characterized by two topographic highs that extend southwest from Gayhead and Squibnocket Point (fig. 12). These highs are interpreted to be undifferentiated coastal plain and continental shelf deposits of Late Cretaceous(?), Tertiary(?), and (or) early Pleistocene(?) age or glacial drift of late Pleistocene (pre-Wisconsinan?) age (QTKu?) that are draped with till associated with the late Wisconsinan Martha's Vineyard moraine. A valley between the till-covered highs is filled with glaciofluvial material that was subsequently incised by late Pleistocene to early Holocene groundwater sapping or fluvial channels, which were subsequently capped with a modern sand body during the Holocene transgression (figs. 12, 16 , and 17).

The Buzzards Bay ice lobe is inferred to have deposited an apron of end moraine (Qdm) material that extended from Chilmark (Stone and DiGacimo-Cohen, 2009) to Nomans Island, which is partially buried by stagnation till, glaciolacustrine, and glaciofluvial deposits along the ablating ice front. Glaciofluvial deposits cropping out beyond the extent of ice-contact deposits likely represent the confluence of meltwater drainage networks of both the Buzzards Bay ice lobe and the Cape Cod Bay ice lobe. The surficial geology of the south shore of Martha's Vineyard between Nomans Island and Katama Bay transitions abruptly from ice-contact deposits, locally capped with younger units, to a broad, massive sheet of outwash material that is locally incised or capped by younger units (fig. 15). The ice-contact material associated with the
Martha's Vineyard moraine of the Buzzards Bay ice lobe(?) is inferred to have been in place before and at a higher elevation than the outwash sediments deposited by the Cape Cod Bay lobe. The margin of the Buzzards Bay ice lobe may have provided a dam for a proglacial lake on the (present-day) shelf that subsequently filled with outwash material from the Cape Cod Bay ice lobe (fig. 10). A prominent reflector interpreted to be coastal plain and continental shelf deposits of Late Cretaceous(?), Tertiary(?), and (or) early Pleistocene(?) age or glacial drift of late Pleistocene (pre-Wisconsinan?) age (QTKu?) may have served to maintain some separation between the sediments of the ice-contact deposits from the Buzzards Bay ice lobe and the outwash sediments from the Cape Cod Bay ice lobe, in a way similar to a lateral moraine. Stratigraphy within the glaciofluvial deposits of the Cape Cod Bay ice lobe east of Chilmark is largely absent, with the exception of a reflector within some glaciofluvial (Qdf) units interpreted to be overlapping lobes of outwash (fig. 13).

North of Nantucket, the glacial stratigraphy visible in the chirp data is limited to glaciofluvial material that presumably overlies glaciolacustrine sediments in the area to the north and east of Tuckernuck Island (Uchupi and Mulligan, 2006). A topographic high that is interpreted as an ice-contact ridge deposit likely associated with late Pleistocene deposits of Coskata and (or) Great Point (Oldale, 1982; Oldale and Barlow, 1986) was incised and separated from the mainland ice-contact unit by postglacial drainage along the eastern side of the Nantucket study area (figs. 11 and 12).

\section{Holocene Depositional Setting}

Postglacial sediments are relatively thick (less than $10 \mathrm{~m}$ ) in a central valley filled with glaciofluvial sediments on the inner continental shelf offshore of Aquinnah on the western side of Martha's Vineyard. The glaciofluvial valley cut into Pleistocene end moraine (Qdm) and older units is incised by a series of postglacial channels, which are truncated by a transgressive sand sheet (Qmn; figs. 12 and 15-17). Elsewhere offshore of Aquinnah, postglacial sediments are largely absent and morainal deposits crop out at the sea floor (figs. 16 and 17). Postglacial sediments are also thick between Squibnocket Point and Nomans Island, where a submerged tombololike sand body has accumulated to greater than $10 \mathrm{~m}$ thick and rests unconformably on glacial ice-contact deposits. Another Holocene sand sheet is partially mapped to the southeast of Nomans Island, and two postglacial fluvial channels meander offshore on either side of Nomans Island. Holocene marine sediments are very thin (typically less than $1 \mathrm{~m}$ ) and discontinuous east of Squibnocket Point, except where postglacial fluvial drainage networks are carved through the outwash to the west and east of South Beach. Two postglacial channels that are not exposed at the surface just west of South Beach, coming out of Edgartown Great Pond, are likely older than adjacent and shallower fluvial or estuarine channels and may owe their origin to groundwater sapping processes described by Uchupi and Oldale (1994). An ebb-tidal delta deposit 
associated with Muskeget Channel caps another large postglacial fluvial channel and the outwash plain on the eastern edge of the Martha's Vineyard study area.

The study area north of Nantucket is covered by a relatively thick (about $5 \mathrm{~m}$ ) layer of Holocene muddy sand deposited in the semienclosed basin north of Nantucket (figs. 11, 12, and 17). Qmn is thinnest along the southwestern edge of the survey area, where outwash sediments cropping out on Nantucket are covered with less than $2 \mathrm{~m}$ of reworked sand and gravel derived from the outwash. Underlying the modern sediment sheet is another relatively thick (about $5 \mathrm{~m}$ ) deposit of late Pleistocene to early Holocene estuarine sediments (Qfe; figs. 11 and 12). A vibracore collected by O'Hara and Oldale (1987), just west of Great Point and about 100 m north of this study area, penetrated the Qfe unit, which was described as a peat deposit with a radiocarbon age of $6,830 \pm 250$ years before present at a depth of $20.5 \mathrm{~m}$ below sea level.

The interpretations of geologic framework presented here indicate that the topography of the glacial terrain has had a substantial influence over patterns of deposition and erosion as Holocene sea level has risen, but less of an influence than in Vineyard and Nantucket Sounds (Baldwin and others, 2016), where strong tidal currents maintain an equilibrium topography that preserves much of the glacial terrain. Along the south and west coasts of Martha's Vineyard, oceanographic conditions driven by wave energy rather than tidal currents modify the sea floor by winnowing and reworking the glacial surface into a gently sloping inner continental shelf. The net effect on the sea floor is a smoothing of its irregularities over time, such that topographic depressions are filled and highs are eroded. Coincident with surface smoothing is the tendency to homogenize surficial sediments wherever sediment can accumulate as a result of critical shear stress. The long-term (40-year) mean significant wave height offshore of the Martha's Vineyard study site is $1.2 \mathrm{~m}$ (Cox and Swail, 2001). The Holocene transgression across this energetic open-ocean coast has created a sandy and relatively smooth inner shelf, where fluvial and glaciofluvial sediments crop out or are buried beneath a thin layer of modern shelf sands or sand waves. In areas where ice-contact sediments exist at or near the surface, the sea floor is more heterogeneous, such that large boulders and cobbles associated with till are left in place and finer sediments are reworked around the erratics. The semiprotected area between Nomans Island and Squibnocket Point provided accommodation space for a large sand body to accumulate (greater than $12 \mathrm{~m}$ thick) in an area where tidal currents and waves refracting around Nomans Island result in sediment accumulation.

The barrier spit that connects Coskata to Great Point formed during the Holocene transgression (Shaler, 1889), creating a semienclosed basin north of Nantucket that is similar to the Holocene depositional conditions in Buzzards Bay described by Foster and others (2015). Quiescent wave and tidal conditions have allowed thick (about 10-m) accumulations of late Pleistocene and early Holocene fluvial, estuarine, and modern marine sediments, which bury the glacial surface locally to depths greater than $20 \mathrm{~m}$.

\section{Summary}

The U.S. Geological Survey, in cooperation with the Massachusetts Office of Coastal Zone Management, compiled previously published seismic-reflection, bathymetric, acousticbackscatter, and sea-floor sediment sample and photograph data to investigate the surficial and shallow subsurface geology offshore of Martha's Vineyard and north of Nantucket. The results are a series of composite geophysical maps with nearly full sea-floor coverage and detailed interpretive maps of the surficial geology and shallow geologic framework of the area. Each of the interpretive maps contributes new insight into the geologic framework and sedimentary environments at a resolution that was previously impossible because of a lack of high-resolution geophysical data. The shallow geologic framework and surficial geology are a complex and variable distribution of sediments and geomorphic features that can be primarily attributed to the advances, occupations, and retreats of Wisconsinan glaciation and to reworking and deposition during the Holocene transgression. Glacial, marine, and terrestrial processes have acted on this region since the late Pleistocene, resulting in a complex geologic history and a heterogeneous sea-floor character. Glacial sediments within the entire region are locally overlain by Holocene fluvial, estuarine, and marine sand and mud.

\section{References Cited}

Ackerman, S.D., Brothers, L.L., Foster, D.S., Andrews, B.D., Baldwin, W.E., and Schwab, W.C., 2016, High-resolution geophysical data from the inner continental shelf-South of Martha's Vineyard and north of Nantucket, Massachusetts: U.S. Geological Survey Open-File Report 2016-1168, 21 p., accessed October 2016 at https://dx.doi.org/10.3133/ ofr20161168.

Andrews, B.D., Ackerman, S.D., Baldwin, W.E., Foster, D.S., and Schwab, W.C., 2014, High-resolution geophysical data from the inner continental shelf at Vineyard Sound, Massachusetts (ver. 2.0, September 2014): U.S. Geological Survey Open-File Report 2012-1006, 1 DVD-ROM. [Also available at https://doi.org/10.3133/ofr20121006.]

Andrews, B.D., Baldwin, W.E., Sampson, D.W., and Schwab, W.C., 2018, Continuous bathymetry and elevation models of the Massachusetts coastal zone and continental shelf (ver. 2.0, April 2018): U.S. Geological Survey data release, accessed May 2018 at https://doi.org/10.5066/F72806T7.

Balco, G., 2011, Contributions and unrealized potential contributions of cosmogenic-nuclide exposure dating to glacier chronology, 1990-2010: Quaternary Science Reviews, v. 30, nos. 1-2, p. 3-27. [Also available at https://doi.org/10.1016/j.quascirev.2010.11.003.] 
Balco, G., Stone, J.O., Porter, S.C., and Caffee, M.W., 2002, Cosmogenic-nuclide ages for New England coastal moraines, Martha's Vineyard and Cape Cod, Massachusetts: Quaternary Science Reviews, v. 21, nos. 20-22, p. 2127-2135. [Also available at https://dx.doi.org/10.1016/ S0277-3791(02)00085-9.]

Baldwin, W.E., Foster, D.S., Pendleton, E.A., Barnhardt, W.A., Schwab, W.C., Andrews, B.D., and Ackerman, S.D., 2016, Shallow geology, sea-floor texture, and physiographic zones of Vineyard Sound and western Nantucket Sound, Massachusetts: U.S. Geological Survey OpenFile Report 2016-1119, accessed September 2, 2016, at https://dx.doi.org/10.3133/ofr20161119.

Barnhardt, W.A., Andrews, B.D., Ackerman, S.D., and Baldwin, W.E., 2009, High-resolution geologic mapping of the inner continental shelf - Cape Ann to Salisbury Beach, Massachusetts: U.S. Geological Survey OpenFile Report 2007-1373, 1 DVD-ROM. [Also available at https://pubs.er.usgs.gov/publication/ofr20071373.]

Barnhardt, W.A., Andrews, B.D., and Butman, B., 2006, High-resolution geologic mapping of the inner continental shelf-Nahant to Gloucester, Massachusetts: U.S. Geological Survey Open-File Report 2005-1293, 1 DVD-ROM. [Also available at https://pubs.er.usgs.gov/publication/ ofr20051293.]

Barnhardt, W.A., Kelley, J.T., Dickson, S.M., and Belknap, D.F., 1998, Mapping the gulf of Maine with side-scan sonar-A new bottom-type classification for complex seafloors: Journal of Coastal Research, v. 14, no. 2, p. 646-659.

Boothroyd, J.C., 2008, Turbine footing placement: NarrBay.org web page, accessed July 8, 2015, at http://www.narrbay.org/d_projects/oceansamp/ gis_marinegeo.htm.

Cox, A.T., and Swail, V.R., 2001., A global wave hindcast over the period 1958-1997-Validation and climate assessment: Journal of Geophysical Research: Oceans, v. 106, no. C2, p. 2313-2329.

Denny, J.F., Danforth, W.W., Foster, D.S., and Sherwood, C.R., 2009, Geophysical data collected off the south shore of Martha's Vineyard, Massachusetts: U.S. Geological Survey Open-File Report 2008-1288. [Also available at https://pubs.er.usgs.gov/publication/ofr20081288.]

Folger, D.W., Hathaway, J.C., Christopher, R.A., Valentine, P.C., and Poag, C.W., 1978, Stratigraphic test well, Nantucket Island, Massachusetts: U.S. Geological Survey Circular 773, 28 p. [Also available at https://doi.org/10.3133/ cir773.]
Ford, K.H., and Voss, S.E., 2010, Seafloor sediment composition in Massachusetts determined using point data: Massachusetts Division of Marine Fisheries Technical Report TR-45, 21 p., accessed June 4, 2013, at http://www.mass.gov/eea/docs/dfg/dmf/publications/ tr-45.pdf.

Foster, D.S., Baldwin, W.E., Barnhardt, W.A., Schwab, W.C., Ackerman, S.D., Andrews, B.D., and Pendleton, E.A., 2015, Shallow geology, sea-floor texture, and physiographic zones of Buzzards Bay, Massachusetts: U.S. Geological Survey Open-File Report 2014-1220, accessed April 2, 2016, at https://dx.doi.org/10.3133/ofr20141220.

Goff, J.A., Mayer, L.A., Traykovski, P., Buynevich, I., Wilkens, R., Raymond, R., Gland, G., Evans, R.L., Olson, H., and Jenkins, C., 2005, Detailed investigation of sorted bedforms, or "rippled scour depressions," within the Martha's Vineyard Coastal Observatory, Massachusetts: Continental Shelf Research, vol. 25, no. 4, p. 461-484. [Also available at https://doi.org/10.1016/j.csr.2004.09.019.]

Gutierrez, B.T., Uchupi, E., Driscoll, N.W., and Aubrey, D.G., 2003, Relative sea-level rise and the development of valley-fill and shallow water sequences in Nantucket Sound, Massachusetts: Marine Geology, v. 193, nos. 3-4, p. 295-314. [Also available at https://doi.org/10.1016/ S0025-3227(02)00665-5.]

Hall, R.E., Poppe, L.J., and Ferrebee, W.M., 1980, A stratigraphic test well, Martha's Vineyard, Massachusetts: U.S. Geological Survey Bulletin 1488, 19 p. [Also available at https://doi.org/10.3133/b1488.]

Kaye, C.A., 1964a, Illinoian and early Wisconsin moraines of Martha's Vineyard, Massachusetts: U.S. Geological Survey Professional Paper 501-C, p. C140-C143. [Also available at https://pubs.er.usgs.gov/publication/pp501C.]

Kaye, C.A., 1964b, Outline of Pleistocene geology of Martha's Vineyard, Massachusetts: U.S. Geological Survey Professional Paper 501-C, p. C134-C139. [Also available at https://pubs.er.usgs.gov/publication/pp501C.]

Kaye, C.A., 1972, Preliminary surficial geologic map of Martha's Vineyard, No Mans Land, and parts of Naushon and Pasque Islands, Massachusetts: U.S. Geological Survey Open-File Report 72-205, 1 sheet.

Kaye, C.A., 1980, Geologic profile of Gay Head Cliff, Martha's Vineyard, Massachusetts: U.S. Geological Survey Open-File Report 80-148, 1 sheet. [Also available at https://doi.org/10.3133/ofr80148.]

Kelley, J.T., Barnhardt, W.A., Belknap, D.F., Dickson, S.M., and Kelley, A.R., 1996, The seafloor revealed-The geology of the northwestern Gulf of Maine inner continental shelf: Maine Geological Survey Open-File Report 96-6, 55 p. 
Kelley, J.T., and Belknap, D.F., 1991, Physiography, surficial sediments and Quaternary stratigraphy of the inner continental shelf and nearshore region of the Gulf of Maine: Continental Shelf Research, v. 11, p. 1265-1283.

Larson, G.J., 1982, Nonsynchronous retreat of ice lobes from southeastern Massachusetts, in Larson, G.J., and Stone, B.D., eds., Late Wisconsinan glaciation of New EnglandA proceeding volume of the symposium, Late Wisconsinan glaciation of New England, held at Philadelphia, Pennsylvania, March 13, 1980: Dubuque, Iowa, Kendall/Hunt, p. 101-113.

Massachusetts Office of Coastal Zone Management, 2015, Sediment mapping-Massachusetts Office of Coastal Zone Mapping's seafloor and habitat mapping program: Massachusetts Office of Coastal Zone Management web page, accessed July 15, 2015, at http://www.mass.gov/eea/ agencies/czm/program-areas/seafloor-and-habitat-mapping/ sediment-mapping/.

Masterson, J.P., Stone, B.D., Walter, D.A., and Savoie, J., 1997, Hydrogeologic framework of western Cape Cod, Massachusetts: U.S. Geological Survey Hydrologic Investigations Atlas HA-741, 1 sheet, scale 1:25,000. [Also available at https://doi.org/10.3133/ha741.]

McMullen, K.Y., Paskevich, V.F., and Poppe, L.J., 2012, GIS data catalog (version 2.2), in Poppe, L.J., Williams, S.J., and Paskevich, V.F., eds., 2005, USGS east-coast sediment analysis - Procedures, database, and GIS data: U.S. Geological Survey Open-File Report 2005-1001, accessed October 2018 at http://woodshole.er.usgs.gov/openfile/of2005-1001/ htmldocs/datacatalog.htm.

McMullen, K.Y., Poppe, L.J., and Soderberg, N.K., 2009, Digital seismic-reflection data from eastern Rhode Island Sound and vicinity, 1975-1980: U.S. Geological Survey Open-File Report 2009-1003, 2 DVD-ROMs. [Also available at https://doi.org/10.3133/ofr20091003.]

O'Hara, C.J., and Oldale, R.N., 1980, Maps showing geology and shallow structure of eastern Rhode Island Sound and Vineyard Sound, Massachusetts: U.S. Geological Survey Miscellaneous Field Studies Map MF-1186, 5 sheets, scale 1:125,000. [Also available at https://doi.org/10.3133/ mf1186.]

O'Hara, C.J., and Oldale, R.N., 1987, Maps showing the geology, shallow structure, and bedforms of Nantucket Sound, Massachusetts: U.S. Geological Survey Miscellaneous Field Studies Map MF-1911, 4 sheets, scale 1:125,000. [Also available at https://doi.org/10.3133/mf1911.]
Oldale, R.N., 1969, Seismic investigations on Cape Cod, Martha's Vineyard, and Nantucket and a topographic map of the basement surface from Cape Cod to the islands, in U.S. Geological Survey, Short papers in geology and hydrology-Articles 122-172-Geological Survey research 1963: U.S. Geological Survey Professional Paper 475-D, p. D118-122. [Also available at https://doi.org/10.3133/ pp475D.]

Oldale, R.N., 1981, Geologic history of Cape Cod, Massachusetts: U.S. Geological Survey General Interest Publication, 23 p., accessed September 23, 2014, at https://pubs.usgs.gov/gip/capecod/.

Oldale, R.N., 1982, Pleistocene stratigraphy of Nantucket, Martha's Vineyard, the Elizabeth Islands, and Cape Cod, Massachusetts, in Larson, G.J., and Stone, B.D., eds., Late Wisconsinan glaciation of New England-A proceeding volume of the symposium, Late Wisconsinan glaciation of New England, held at Philadelphia, Pennsylvania, March 13, 1980: Dubuque, Iowa, Kendall/Hunt, p. 1-34.

Oldale, R.N., 2001, Cape Cod, Martha's Vineyard and Nantucket-The geologic story revised and updated: East Orleans, Mass., Parnassus Imprints, 208 p.

Oldale, R.N., and Barlow, R.A., 1986, Geologic map of Cape Cod and the Islands, Massachusetts: U.S. Geological Survey Miscellaneous Investigations Series Map I-1763, 1 sheet, scale 1:100,000.

Oldale, R.N., and Eskenasy, D.M., 1982, Regional significance of pre-Wisconsinan till from Nantucket Island, Massachusetts: Quaternary Research, v. 19, no. 3, p. 302-311.

Oldale, R.N., and O'Hara, C.J., 1984, Glaciotectonic origin of the Massachusetts coastal end moraines and a fluctuating late Wisconsinan ice margin: Geological Society of America Bulletin, v. 95, p. 61-74.

Oldale, R.N., Uchupi, E., and Prada, K.E., 1973, Sedimentary framework of the western Gulf of Maine and the southeastern Massachusetts offshore area: U.S. Geological Survey Professional Paper 757, $10 \mathrm{p}$. and $2 \mathrm{pl}$. [Also available at https://doi.org/10.3133/pp757.]

Oldale, R.N., Valentine, P.C., Cronin, T.M., Spiker, E.C., Blackwelder, B.W., Belknap, D.F., Wehmiller, J.F., and Szabo, B.J., 1982, Stratigraphy, structure, absolute age, and paleontology of the upper Pleistocene deposits at Sankaty Head, Nantucket Island, Massachusetts: Geology, v. 10, no. 5, p. 246-252. 
Pendleton, E.A., Baldwin, W.E., Barnhardt, W.A., Ackerman, S.D., Foster, D.S., Andrews, B.D., and Schwab, W.C., 2013, Shallow geology, seafloor texture, and physiographic zones of the inner continental shelf from Nahant to northern Cape Cod Bay, Massachusetts: U.S. Geological Survey OpenFile Report 2012-1157, 53 p., accessed August 2013 at http://pubs.usgs.gov/of/2012/1157/.

Pendleton, E.A., Baldwin, W.E., Foster, D.F., Ackerman, S.D., Andrews, B.D, Brothers, L.L., and Schwab, W.C., 2018, Geospatial data layers of shallow geology, sea-floor texture, and physiographic zones from the inner continental shelf of Martha's Vineyard from Aquinnah to Wasque Point, and Nantucket from Eel Point to Great Point: U.S. Geological Survey data release, https://doi.org/10.5066/P9E9EFNE.

Pendleton, E.A., Barnhardt, W.A., Baldwin, W.E., Foster, D.S., Schwab, W.C., Andrews, B.D., and Ackerman, S.D., 2015, Sea-floor texture and physiographic zones of the inner continental shelf from Salisbury to Nahant, Massachusetts, including the Merrimack Embayment and Western Massachusetts Bay: U.S. Geological Survey Open-File Report 2015-1153, 36 p., 1 appendix, accessed April 2, 2016, at https://dx.doi.org/10.3133/ofr20151153.

Ridge, J.C., 2004, The Quaternary glaciation of western New England with correlations to surrounding areas, in Ehlers, J. and Gibbard, P.L., eds., Quaternary glaciations-Extent and chronology, Part II- North America: Amsterdam, The Netherlands, Elsevier, p. 169-198.

Robb, J.M., and Oldale, R.N., 1977, Preliminary geologic maps, Buzzards Bay, Massachusetts: U.S. Geological Survey Miscellaneous Field Studies Map MF-889, 2 sheets, scale 1:107,500. [Also available at https://doi.org/10.3133/ mf889.]

Rosen, P.S., 1972, Evolution and processes of Coatue Beach, Nantucket Island, Massachusetts: A cuspate spit shoreline: Amherst, Mass., University of Massachusetts, master's thesis, $202 \mathrm{p}$.

Shaler, N., 1889, The Geology of Nantucket: U.S. Geological Survey Bulletin 53, $55 \mathrm{p}$.

Siegel, J., Dugan, B., Lizarralde, D., Person, M., DeFoor, W., and Miller, N., 2012, Geophysical evidence of a late Pleistocene glaciation and paleo-ice stream on the Atlantic continental shelf offshore Massachusetts, USA: Marine Geology, v. 303-306, p. 63-74. [Also available at https://doi.org/10.1016/j.margeo.2012.01.007.]

Stone, B.D., and DiGiacomo-Cohen, M.L., comps., 2009, Surficial geologic map of the Pocasset-ProvincetownCuttyhunk-Nantucket 24-quadrangle area of Cape Cod and Islands, southeast Massachusetts: U.S. Geological Survey Open-File Report 2006-1260-E, 24 sheets, scale 1:24,000, 23 p. text. [Also available at https://doi.org/10.3133/ ofr20061260E.]
Stone, B.D., Stone, J.R., DiGiacomo-Cohen, M.L., and Kincare, K.A., comps., 2011, Surficial geologic map of the Norton-Manomet-Westport-Sconticut Neck 23-quadrangle area in southeast Massachusetts: U.S. Geological Survey Open-File Report 2006-1260-F, 21 sheets, scale 1:24,000, 22 p. text. [Also available at https://doi.org/10.3133/ ofr20061260F.]

Stone, J.R., Schafer, J.P., London, E.H., DiGiacomo-Cohen, M.L., Lewis, R.S., and Thompson, W.B., 2005, Quaternary geologic map of Connecticut and Long Island Sound basin: U.S. Geological Survey Scientific Investigations Map 2784, 2 sheets, scale 1:125,000. [Also available at https://doi.org/10.3133/sim2784.]

Uchupi, E., Giese, G.S., Aubrey, D.G., and Kim, D.J., 1996, The late Quaternary construction of Cape Cod, Massachusetts - A reconsideration of the W.M. Davis model: Geological Society of America Special Paper, v. 309, 69 p. [Also available at http://specialpapers.gsapubs.org/ content/309/1.full.pdf.]

Uchupi, E., and Mulligan, A.E., 2006, Late Pleistocene stratigraphy of upper Cape Cod and Nantucket Sound, Massachusetts: Marine Geology, v. 227, nos. 1-2, p. 93-118. [Also available at https://doi.org/10.1016/j.margeo.2005.11.012.]

Uchupi, E., and Oldale, R.N., 1994, Spring sapping origin of the enigmatic relict valleys of Cape Cod and Martha's Vineyard and Nantucket islands, Massachusetts: Geomorphology, v. 9, no. 2, p. 83-95. [Also available at https://doi.org/10.1016/0169-555X(94)90068-X.]

Weed, E.G.A., Minard, J.P., Perry, W.J., Jr., Rhodehamel, E.C., and Robbins, E.I., 1974, Generalized pre-Pleistocene geologic map of the northern United States Atlantic continental margin: U.S. Geological Survey Miscellaneous Investigations Series Map I-861, 2 sheets, scale 1:1,000,000. [Also available at https://doi.org/10.3133/i861.]

Wentworth, C.K., 1922, A scale of grade and class terms for clastic sediments: Journal of Geology, v. 30, p. 377-392.

Woodsworth, J.B., and Wigglesworth, E., 1934, Geology and geography of the region including Cape Cod, the Elizabeth Islands, Nantucket, Martha's Vineyard, No Man's Land, and Block Island: Museum Comparative Zoology Memoirs, v. 52,322 p.

Zen, E-an, Goldsmith, R., Ratcliffe, N.M., Robinson, P., and Stanley, R.S., 1983, Bedrock geologic map of Massachusetts: U.S. Geological Survey Unnumbered Series, 3 sheets, scale 1:250,000. 
Appendix 1 



\section{Appendix 1. Links to Geospatial Data Layers}

Geospatial data layers described in this report are available in a companion U.S. Geological Survey data release at https://doi.org/10.5066/P9E9EFNE (table 1.1; Pendleton and others, 2018). All vector data are delivered as Esri shapefiles in the geographic coordinate system, referenced to the World Geodetic System of 1984 (WGS 84). Raster representations of seismic interpretation interpretations are GeoTIFF formats in Universal Transverse Mercator projection, Zone 19N, WGS 84 datum. All spatial data are distributed with Federal Geographic Data Committee-compliant metadata.

\section{Reference Cited}

Pendleton, E.A., Baldwin, W.E., Foster, D.F., Ackerman, S.D., Andrews, B.D., Brothers, L.L., and Schwab, W.C., 2018, Geospatial data layers of shallow geology, sea-floor texture, and physiographic zones from the inner continental shelf of Martha's Vineyard from Aquinnah to Wasque Point, and Nantucket from Eel Point to Great Point: U.S. Geological Survey data release, https://doi.org/10.5066/P9E9EFNE.

Table 1.1. Links to geospatial data layers.

\begin{tabular}{|c|c|c|}
\hline Filename and description & $\begin{array}{c}\text { Federal Geographic Data } \\
\text { Committee metadata }\end{array}$ & Data and metadata download \\
\hline $\begin{array}{l}\text { Backscatter mosaic: } \\
\text { 5-m backscatter mosaic from south and west of Martha's Vineyard } \\
\text { and north of Nantucket produced from sidescan-sonar and inter- } \\
\text { ferometric backscatter datasets }\end{array}$ & HTML & MV_ACK_backscatter_5m.zip \\
\hline $\begin{array}{l}\text { Regressive unconformity: } \\
\text { Elevation of the late Wisconsinan to early Holocene regressive } \\
\text { unconformity }\left(\mathrm{U}_{\mathrm{r}}\right) \text { offshore of western and southern Martha's } \\
\text { Vineyard and north of Nantucket, Massachusetts }\end{array}$ & HTML & MV_ACK_depth2G.zip \\
\hline $\begin{array}{l}\text { Holocene sediment isopach: } \\
\text { Holocene fluvial and estuarine (Qfe) and nearshore marine (Qmn) } \\
\text { sediment thickness offshore of western and southern Martha's } \\
\text { Vineyard and north of Nantucket, Massachusetts }\end{array}$ & HTML & MV_ACK_postGisopach.zip \\
\hline $\begin{array}{l}\text { Physiographic zones: } \\
\text { Physiographic Zones of the Sea Floor offshore of western and } \\
\text { southern Martha's Vineyard and north of Nantucket, Massachu- } \\
\text { setts }\end{array}$ & HTML & MV_ACK_physiozone.zip \\
\hline $\begin{array}{l}\text { Sediment texture: } \\
\text { Sediment Texture of the Sea Floor offshore of western and southern } \\
\text { Martha's Vineyard and north of Nantucket, Massachusetts }\end{array}$ & HTML & MV_ACK_sedtexture.zip \\
\hline
\end{tabular}



For more information about this report, contact:

Director, Woods Hole Coastal and Marine

Science Center

U.S. Geological Survey

384 Woods Hole Road

Quissett Campus

Woods Hole, MA 02543-1598

WHSC_science_director@usgs.gov

(508) 548-8700 or (508) 457-2200

or visit our website at

https://woodshole.er.usgs.gov

Publishing support provided by the

Pembroke Publishing Service Center 
